Check for updates

Cite this: Phys. Chem. Chem. Phys., 2021, 23, 3195

\section{Pickup and reactions of molecules on clusters relevant for atmospheric and interstellar processes}

\author{
Michal Fárník, (D) *a Juraj Fedor, (DD ${ }^{a}$ Jaroslav Kočišek, (D) ${ }^{a}$ Jozef Lengyel, (D) ${ }^{b}$ \\ Eva Pluhařová, (D) ${ }^{a}$ Viktoriya Poterya ${ }^{a}$ and Andriy Pysanenko
}

\begin{abstract}
In this perspective, we review experiments with molecules picked up on large clusters in molecular beams with the focus on the processes in atmospheric and interstellar chemistry. First, we concentrate on the pickup itself, and we discuss the pickup cross sections. We measure the uptake of different atmospheric molecules on mixed nitric acid-water clusters and determine the accommodation coefficients relevant for aerosol formation in the Earth's atmosphere. Then the coagulation of the adsorbed molecules on the clusters is investigated. In the second part of this perspective, we review examples of different processes triggered by UV-photons or electrons in the clusters with embedded molecules. We start with the photodissociation of hydrogen halides and Freon $\mathrm{CF}_{2} \mathrm{Cl}_{2}$ on ice nanoparticles in connection with the polar stratospheric ozone depletion. Next, we mention reactions following the excitation and ionization of the molecules adsorbed on clusters. The first ionization-triggered reaction observed between two different molecules picked up on the cluster was the proton transfer between methanol and formic acid deposited on large argon clusters. Finally, negative ion reactions after slow electron attachment are illustrated by two examples: mixed nitric acid-water clusters, and hydrogen peroxide deposited on large $\operatorname{Ar}_{N}$ and $\left(\mathrm{H}_{2} \mathrm{O}\right)_{N}$ clusters. The selected examples are discussed from the perspective of the atmospheric and interstellar chemistry, and several future directions are proposed.
\end{abstract}

Received 25th November 2020 Accepted 9th January 2021

DOI: $10.1039 / \mathrm{d} 0 \mathrm{cp} 06127 \mathrm{a}$

rsc.li/pccp

\section{Introduction}

Clusters of atoms and molecules have been investigated in molecular beams since the conception of the molecular beam technique and became a very broad field covered in many reviews and textbooks. ${ }^{1-8}$ One of the original motivations to study clusters stems from the aspiration to understand bulk materials based on the properties of the individual atoms and molecules, since the clusters can bridge the gas and condensed phases. ${ }^{5,6}$ From another perspective, clusters can provide insight into the solvent effects in chemistry and physics at a molecular level. ${ }^{9,10}$ In addition, clusters have their own intrinsic properties, different from the gas and condensed phases, that give rise to the cluster-specific physics and chemistry, ${ }^{4,6,11}$ which find many applications, e.g., in nanocatalysis. ${ }^{12,13}$ The modern cluster research spans different disciplines from physics and chemistry, to biology, materials science and astronomy. ${ }^{14}$

\footnotetext{
${ }^{a} J$. Heyrovsky Institute of Physical Chemistry, v.v.i., The Czech Academy of Sciences, Dolejškova 2155/3, 18223 Prague, Czech Republic

E-mail: michal.farnik@jh-inst.cas.cz

${ }^{b}$ Chair of Physical Chemistry, Department of Chemistry, Technical University of Munich, 85748 Garching, Germany
}

The clusters in molecular beams can be doped by other molecules and used as nanomatrices or nanoreactors for molecular spectroscopy and chemical reactions. In this respect, large helium clusters known as He-nanodroplets have been largely exploited and represent a rather special case. They can efficiently capture molecules and provide an extremely cold $(0.37 \mathrm{~K})^{15}$ and superfluid environment for molecular spectroscopy and reactions, as outlined in many studies and recent reviews. ${ }^{16-21}$

The pickup of molecules and their reactions especially on large argon clusters were implemented to investigate the solvent effect on reaction dynamics, and the pioneering technique was termed Cluster Isolated Chemical Reactions (CICR) and reviewed by Mestdagh et al. more than 20 years ago. ${ }^{22}$ For the product detection, most of the early CICR experiments considered chemiluminescence, namely the prototypical reaction of the barium atom with $\mathrm{N}_{2} \mathrm{O}$ yielding the chemiluminescent product $\mathrm{BaO}^{23}$ Further reactions of $\mathrm{Ba}$ with $\mathrm{CH}_{4}, \mathrm{Cl}_{2}, \mathrm{O}_{2}, \mathrm{CO}_{2}$ and $\mathrm{SF}_{6}$ were studied. ${ }^{24-29}$ The CICR technique has been further exploited for investigations of reactions, ${ }^{30}$ spectroscopy,${ }^{31}$ photoinduced $\mathrm{Ca}+\mathrm{HBr}$ and $\mathrm{Ca}+\mathrm{CH}_{3} \mathrm{~F}$ reactions ${ }^{32,33}$ or more recent investigation of solvation dynamics. ${ }^{34,35}$ The rare gas clusters were also implemented in the investigation of the solvent effect on the 
photodissociation dynamics in Buck's group, where the molecules were deposited in the clusters and dissociated by UV lasers. ${ }^{36-38}$ Our present work, in a sense, follows up on the CICR methodology, and extends it towards applications in atmospheric and interstellar chemistry.

From the point of view of astrochemistry, ice and dust grains offer surfaces for chemical reactions in the environment of interstellar medium, where collisions between molecules are infrequent and inefficient for reactions to proceed. ${ }^{39-41}$ The processes on interstellar ice and dust nanoparticles can be mimicked by reactions of molecules on clusters in molecular beam experiments. From the perspective of atmospheric chemistry, the cluster research can provide detailed insight into aerosol formation and reactions. ${ }^{42,43}$ Despite huge experimental and theoretical efforts, aerosol particles still belong to the least known players in atmospheric chemistry. ${ }^{42,44-47}$ Nevertheless, their importance is unquestionable; among many other effects, they provide surfaces for heterogeneous chemistry and photochemistry. ${ }^{44,48,49}$ Even small pure water clusters were found to mediate chemistry in the atmosphere. ${ }^{50}$ Clusters in molecular beams can represent proxies for atmospheric and interstellar aerosols in laboratory experiments. Early studies by Castleman's group investigated atmospherically relevant phenomena, such as nitric acid solvation and dissolution in water clusters, ${ }^{51,52}$ and further cluster ion reactions. ${ }^{53,54}$ Many recent examples exist in the literature exploiting mass spectrometry, ${ }^{43,55-57}$ spectroscopy, ${ }^{58-61}$ photodissociation ${ }^{62,63}$ and other molecular beam experiments with atmospherically and astrochemically relevant clusters. ${ }^{43,64}$

Here, we focus on the special experiments with clusters, where different molecules are deposited on the clusters in pickup processes, and subsequently, reactions between the molecules on/in the clusters can be triggered by photons or electrons, as illustrated schematically in Fig. 1. We review some of our work and the related experiments of other groups in the broader context of atmospheric and interstellar chemistry. In the spirit of the perspective article, we also report some unpublished results, and suggest future directions in this field.

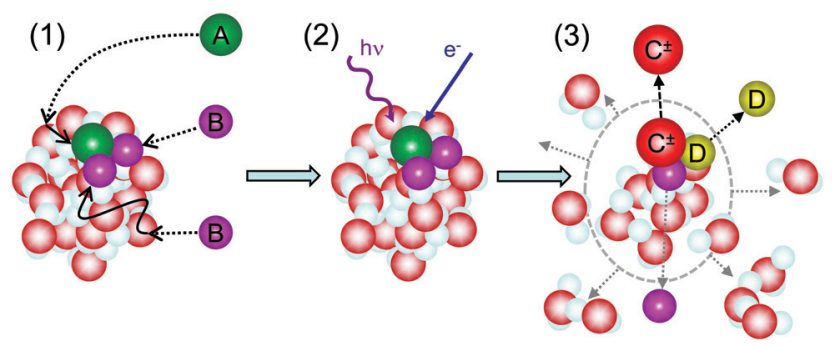

Fig. 1 Schematic illustration of the cluster processes reviewed here from the perspective of atmospheric and interstellar physics and chemistry: (1) pickup of molecules A and B on clusters and their coagulation (Section 3), and (2) reactions triggered by electrons and/or photons $\mathrm{A}+\mathrm{B}+$ $e^{-}(h \nu) \stackrel{\text { cluster }}{\longrightarrow} \mathrm{C}^{ \pm}+\mathrm{D}$ (Section 4); (3) the reaction products can be ejected or the clusters decay upon excitation and the positively or negatively charged products $\mathrm{C}^{ \pm}$are detected.
The article is organized as follows: Section 2 briefly describes our cluster beam apparatus. The pickup technique is introduced in Section 3, and exploited for cluster characterization (Section 3.1), and for mimicking the processes of atmospheric aerosol nucleation (Section 3.2) using pure ice nanoparticles (Section 3.2.1) and nitric acid-water clusters (Section 3.2.2). In Section 3.3, pickup on clusters relevant for interstellar chemistry is briefly discussed. The molecules adsorbed on large clusters can coagulate, which is discussed in Section 3.4. Reactions on the clusters are discussed in Section 4, starting with photodissociation (Section 4.1). Further, we show examples of reactions on the clusters between the adsorbed molecules after their ionization or excitation by photons or electrons (Section 4.2). Finally, we review some reactions initiated by slow electron attachment (Section 4.3). We close by summarizing the general observations and possible future directions.

\section{CLUB experiment}

The cluster pickup experiments reviewed here were mostly performed using the cluster beam apparatus (CLUB) in Prague (Fig. 2). ${ }^{43}$ The CLUB is based on the apparatus used originally for photodissociation experiments in the group of $\mathrm{U}$. Buck, ${ }^{36}$ which was extended in our laboratory as a versatile tool for various cluster experiments. The different experiments can be done with the same cluster beam probing the same species and thus the results can provide information about different properties of the same clusters.

The clusters are produced in the nozzle chamber (NC) by supersonic continuous expansion through a conical nozzle (typically $50-130 \mu \mathrm{m}$ in diameter, full opening angle of $30 \mathrm{deg}$, length $2 \mathrm{~mm}$ ). The nozzle can be attached to different cluster sources. A simple rare gas cluster source consists essentially of a tube kept at a controlled temperature via external heating and cooling. More sophisticated sources are used for evaporation of liquid and solid samples such as polycyclic hydrocarbons and simple biomolecules. A special case is the recently developed source of microsolvated molecules described in ref. 65. Fig. 2 shows the CLUB with the

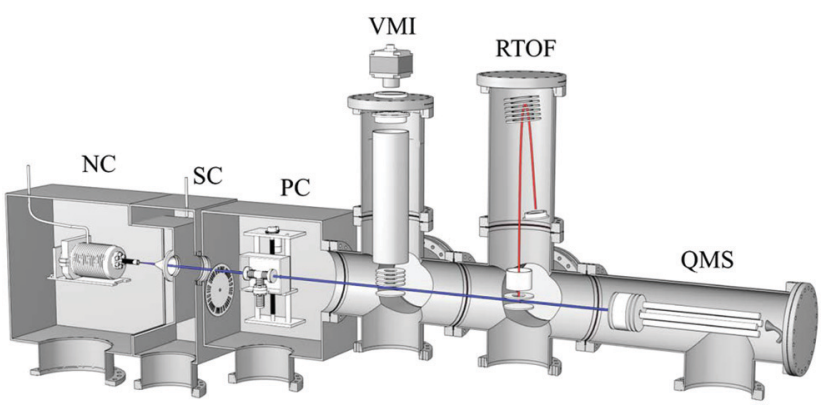

Fig. 2 Schematic overview of the cluster beam apparatus (CLUB): nozzle chamber (NC), scattering chamber (SC), pickup chamber (PC) with a pickup cell and a pseudorandom chopper, velocity map imaging (VMI), reflectron time-of-flight mass spectrometer (RTOF), and quadrupole mass spectrometer (QMS). 
sketch of a water cluster source in the NC. The continuous expansion allows achieving stable and well reproducible cluster generation, and the conical nozzle shape ensures efficient clustering and sufficient beam densities along the entire cluster beam path of about $2 \mathrm{~m}$.

The cluster beam passes through a skimmer into a differentially pumped scattering chamber (SC), which is used as the first pickup chamber in the present pickup experiments. In the next vacuum chamber (PC), further two pickup cells can be inserted in the cluster beam. In Fig. 2, only one pickup cell is drawn, which has recently been developed for the pickup of hydrogen peroxide. ${ }^{66}$ A pseudorandom chopper is located in this vacuum chamber as well, which allows for accurate velocity measurements of the clusters, exploited in the cross section measurements discussed below. ${ }^{67-69}$

The following chamber is devoted to the photodissociation experiments using velocity map imaging (VMI). Our VMI setup and its first implementation in the CLUB are described elsewhere. ${ }^{62,70}$ Various UV lasers are available in the laboratory for the photolysis and resonance enhanced multiphoton ionization (REMPI) of the photodissociation fragments, and IR lasers can be also used for IR-UV experiments. ${ }^{71}$

The reflectron time-of-flight mass spectrometer (RTOF) in the next chamber was first described in ref. 72 and 73 . The clusters can be ionized by different methods: electron ionization introduced in the first studies, ${ }^{72,73}$ multiphoton processes using UV lasers, ${ }^{74,75}$ or by the special method of Na-doping and subsequent electron photodetachment. ${ }^{72,76,77}$ We use also electron attachment and negative cluster ion mass spectrometry. ${ }^{78}$ These different ionization methods can produce quite different mass spectra from the same clusters, and information about the original neutral clusters can be recovered by their combination. An example represents the investigation of the mixed nitric oxide-water clusters by electron ionization, Na-doping, and electron attachment. ${ }^{79}$

Some of our mass spectrometry experiments have recently been reviewed. ${ }^{43}$ The power of the combination of VMI with high-resolution RTOF mass spectrometry has been illustrated for a few examples investigating the photodissociation dynamics of molecules in clusters, where the complex information about the nature of the clusters could not be revealed by VMI or mass spectrometry experiments alone. ${ }^{80,81}$

A quadrupole mass spectrometer (QMS) with continuous electron ionization is mounted in the last chamber. It can be used to monitor the molecular beam, or to measure the beam velocity by the time-of-flight in connection with the chopper in the PC chamber. ${ }^{67,68}$

\section{Uptake of molecules on clusters}

The pickup technique has been used since the $1980 \mathrm{~s}^{82}$ for doping clusters with different molecules as the cluster beam passes through a diluted gas and the gas molecules are embedded in the clusters upon sticking collisions. It has been exploited especially in experiments with He-nanodroplets, where numerous examples exist, e.g., for spectroscopy, ${ }^{15,18,19,83,84}$ reactions, ${ }^{20,21,85-90}$ and generation of clusters ${ }^{91}$ in the cold superfluid environment of He-nanodroplets. Interesting applications have recently been developed, such as the decoration and visualization of superfluid vorticies with atoms in He-nanodroplets. ${ }^{92,93}$

Here we focus on large water clusters $\left(\mathrm{H}_{2} \mathrm{O}\right)_{N}$ (ice nanoparticles) and other molecular species such as, e.g., nitric acid-water clusters. We often perform analogous pickup experiments also with the $\operatorname{Ar}_{N}$ clusters for comparison of the molecular cluster with the inert environment of the rare-gas cluster. The pickup of molecules on $\operatorname{Ar}_{N}$ was reviewed in the context of the CICR method. ${ }^{22}$ Huisken and Stemmler used $\operatorname{Ar}_{N}$ for infrared spectroscopy of adsorbed methanol clusters. ${ }^{94}$ The pickup of hydrogen halide molecules on large rare gas clusters was implemented in Buck's group for the photodissociation studies. $^{36-38}$ Among molecular clusters, especially water clusters were used for uptake of different molecules. ${ }^{95-98}$ A rather special example is the pickup of $\mathrm{Na}$ atoms, ${ }^{99,100}$ which was exploited for mass spectrometry and size resolved investigations of large water, ammonia, and other clusters. ${ }^{101-104}$

An interesting implementation of the pickup technique was exploited to develop the Exchange Metal Cluster source (EXMEC): ${ }^{105}$ argon clusters were first generated by supersonic expansion, which then entered the pickup cell with metal vapor or other atoms or molecules; the picked up species eventually replaced the Ar atoms in the cluster completely, and clusters composed purely of metal atoms or other species then left the source. This method was used to produce small neutral clusters of several different elements and compounds, especially alkali halide clusters. ${ }^{106-109}$ Water clusters were used in these experiments as the primary clusters to investigate the solvation effects on alkali-halides. ${ }^{110,111}$

\subsection{Pickup cross section}

In a pickup experiment, the cluster flies through a very diluted gas and collides with the gas molecules, which can stick to the cluster. This process can be characterized by the cluster pickup cross section. The pickup cross section depends on the cluster size, i.e., on its geometrical cross section, and on the size of the molecule (see Fig. 3). The geometrical pickup cross section can be written as $\sigma_{\mathrm{pu}}^{\mathrm{g}}=\pi \cdot\left(R_{N}+r_{m}\right)^{2}$, where $R_{N}$ and $r_{m}$ are the radius of the cluster and the molecule, respectively. However, the actual pickup cross section can be significantly larger than the geometrical one, since the molecules can be attracted to the cluster due to the long-range interactions between the cluster and the molecules even from distances outside of the area corresponding to $\sigma_{\mathrm{pu}}^{\mathrm{g}}$. On the other hand, the pickup cross section includes also the sticking probability of the molecule to the cluster, which can be smaller than one. In addition, the collision and sticking probabilities depend on the collision energy. Thus the pickup is a complex process and some of these points were investigated in the references reviewed in this section and will be discussed below.

One of the early implementations of the pickup technique was to determine the size of the large neutral clusters. ${ }^{112}$ The measurement of the cluster size in a molecular beam is difficult. 


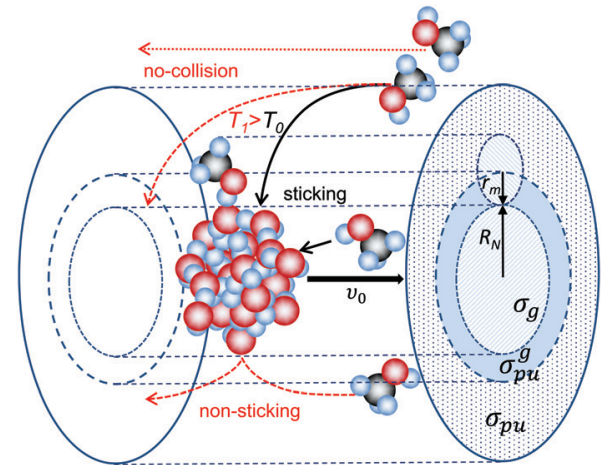

Fig. 3 Schematic picture of the pickup processes illustrating the cluster geometrical cross section $\sigma_{\mathrm{g}}=\pi \cdot R_{N}{ }^{2}$, geometrical pickup cross section $\sigma_{\mathrm{pu}}^{\mathrm{g}}=\pi \cdot\left(R_{N}+r_{m}\right)^{2}$, and pickup cross section $\sigma_{\mathrm{pu}}$. The pickup cross section depends also on the probability of the sticking collision, and the collision probability is a function of the collision energy $T$.

Mass spectrometry involves ionization, which can cause severe cluster fragmentation. ${ }^{43,76}$ Even the threshold photoionization, which can be relatively soft, can cause fragmentation in some cases. ${ }^{113,114}$ For large clusters, other methods were used, e.g. high energy electron diffraction, ${ }^{115-119}$ helium atom diffraction, ${ }^{120}$ and cluster beam scattering by a buffer gas. ${ }^{121}$ Some special methods were developed, such as elastic scattering ${ }^{122-124}$ and sodium doping with subsequent photodetachment of electrons, ${ }^{101,102}$ the latter of which was later proposed as the sizer for neutral weakly bound ultrafine aerosol particles. ${ }^{103,104}$ Clusters can be also deflected according to their sizes in strong inhomogeneous electric fields due to their size-dependent dipole moments and polarizability, ${ }^{125-127}$ which is, however, limited to small complexes. None of the above methods is universal. Elastic scattering is fairly elaborate and applicable only for small clusters, and Nadoping worked nicely with water and ammonia, ${ }^{101}$ and some other clusters, ${ }^{103,104,113}$ yet, it turned out not to be applicable for clusters containing molecules reacting with the solvated electron. ${ }^{72,77,79,128}$

Alternatively, the cluster size can be determined by the methods based on the pickup. Historically, there have been essentially two approaches: in the first one, sticking collisions of molecules with clusters lead to momentum transfer, and thus by measuring the variations of the average cluster beam velocity with the number of collisions (the pickup gas pressure) the mean cluster size could be determined. ${ }^{112}$ The second approach relies on measuring the Poisson distributions of the adsorbed molecules. ${ }^{129}$ We have compared and combined these two methods for the pickup of different molecules on $\operatorname{Ar}_{N}$ clusters, and established a method to determine the pickup cross sections. ${ }^{67}$

The original methods ${ }^{112,129}$ required certain knowledge about the pickup cross section $\sigma_{\mathrm{pu}}$ in order to evaluate the cluster mean size $\bar{N}$. The simplest assumption was to put the pickup cross section of a large cluster equal to its geometrical pickup cross section $\sigma_{\mathrm{pu}}^{\mathrm{g}}$, which could be simply determined from the hard sphere geometrical cross section $\sigma_{\mathrm{g}}$ assuming a spherical cluster shape and close packing of the molecules in the cluster. This assumption reduced the unknown parameters to only the cluster size $\bar{N}$, and thus $\bar{N}$ could be determined from the experiments. However $\sigma_{\mathrm{pu}}$ could be significantly different from $\sigma_{\mathrm{pu}}^{\mathrm{g}}$, as discussed below. Already in their original paper, Cuvellier et $a .^{112}$ used collision dynamics simulations to account for a more realistic attractive interaction between the molecule and the $\operatorname{Ar}_{N}$ cluster yielding a correction to $\sigma_{\mathrm{pu}}^{\mathrm{g}}$. Another theoretical study of the role of long-range forces in the cluster-molecule collisions for $\operatorname{Ar}_{N}$ resulted also in the capture cross sections larger than the geometrical ones. ${ }^{130}$ In our experiments, ${ }^{67}$ we worked with the $\operatorname{Ar}_{N}$ clusters, for which the mean size $\bar{N}$ was known from the expansion conditions based on semiempirical Hagena's scaling laws, ${ }^{131-133}$ confirmed experimentally by helium atom diffraction. ${ }^{120}$ The independent determination of $\bar{N}$ for $\operatorname{Ar}_{N}$ clusters allowed the evaluation of the pickup cross sections $\sigma_{\mathrm{pu}}$ from our velocity measurements, and we have confirmed our measured cross sections with molecular dynamics (MD) and Monte-Carlo simulations. ${ }^{67}$

The water $\left(\mathrm{H}_{2} \mathrm{O}\right)_{N}$ clusters represent another example, for which the mean cluster size $\bar{N}$ was determined by independent experiments. ${ }^{101}$ Thus, we could measure the pickup cross sections for uptake of different molecules on large water clusters. ${ }^{68}$ The pickup cross sections were measured for $\operatorname{Ar}_{N}$ and $\left(\mathrm{H}_{2} \mathrm{O}\right)_{N}$ in the size range of $\bar{N} \approx 50-600$ and compared to MD simulations as well as to an analytical model. ${ }^{69}$ The pickup cross sections for both $\operatorname{Ar}_{N}$ and $\left(\mathrm{H}_{2} \mathrm{O}\right)_{N}$ were larger than the corresponding geometrical pickup cross sections; however, there was also a difference in the cross section size dependence. While the pickup cross sections for $\operatorname{Ar}_{N}$ were consistent with their assumed spherical shapes, the cross sections of $\left(\mathrm{H}_{2} \mathrm{O}\right)_{N}$ departed from the spherical cluster model for $\bar{N} \geq 300$ towards larger values. The larger cross sections could be justified by assuming irregular shapes. These clusters occur in supersonic expansions under the conditions where large clusters are generated by smaller cluster coagulation rather than by the addition of the individual molecules. Thus the pickup experiments delivered not only the cluster pickup cross sections $\sigma_{\mathrm{pu}}$ but also indirect information about the cluster shape. $^{69}$

The velocity measurements for cluster size determination were implemented also by Kresin et al. ${ }^{134}$ They used the momentum transfer in a single sticking collision, which was proved by the mass spectrometry of isotopically labeled species, to determine the neutral $\left(\mathrm{H}_{2} \mathrm{O}\right)_{N}$ and $\left(\mathrm{D}_{2} \mathrm{O}\right)_{N}$ cluster sizes of smaller clusters $(N \leq 50)$. These results confirmed the extensive water cluster fragmentation after electron ionization observed previously, ${ }^{76}$ emphasizing the conclusion that the simple mass spectrometry might be misleading for cluster size determination.

\subsection{Mimicking atmospheric aerosol nucleation}

3.2.1 Ice nanoparticles. The pickup cross sections reviewed above are important parameters in the modeling of aerosol formation and growth in the atmosphere. We have measured the pickup cross sections of ice nanoparticles $\left(\mathrm{H}_{2} \mathrm{O}\right)_{N}$ of mean 
size $\bar{N} \approx 260$ for various atmospherically relevant molecules $\left(\mathrm{H}_{2} \mathrm{O}, \mathrm{HCl}, \mathrm{HBr}, \mathrm{NO}, \mathrm{NO}_{2}, \mathrm{CH}_{3} \mathrm{OH}, \mathrm{CH}_{3} \mathrm{CH}_{2} \mathrm{OH}, \mathrm{CH}_{4}\right) .{ }^{68}$ The pickup cross sections for the uptake of $\mathrm{H}_{2} \mathrm{O}$ molecules on $\left(\mathrm{H}_{2} \mathrm{O}\right)_{N}$ are useful for modeling of the uptake of water molecules on aqueous particles, although the homogeneous nucleation of water is unlikely to occur in the Earth's atmosphere. The spherical cluster radius corresponds to $R_{N}=r_{0} \cdot N^{1 / 3}$, where $r_{0}$ $\approx 2 \AA$ could be obtained from the theoretical calculations. ${ }^{135}$ The corresponding geometrical pickup cross section was $\sigma_{\mathrm{pu}}^{\mathrm{g}}=$ $685 \AA^{2}$; however, the experimentally measured cross section was significantly larger, $\sigma_{\mathrm{pu}}=1020 \pm 100 \AA^{2}$. This was due to the attractive interaction between the water molecule and the cluster as shown by our MD simulations using realistic interaction potentials for water, which yielded a cross section of $950 \AA^{2} .^{68}$

The pickup cross section depends also on the molecular mass and collision velocity. Our measured pickup cross section for the uptake of $\mathrm{H}_{2} \mathrm{O}$ molecules on ice nanoparticles was larger than the simple geometrical cross section by at least a factor of 1.5. However, it can be further enhanced under atmospheric conditions by lower collision speed $\left(\sim 500 \mathrm{~ms}^{-1}\right)$ compared to our cluster beam experiment $\left(v_{0}=1450 \mathrm{~ms}^{-1}\right)$. This could enhance the pickup cross section by another factor of $\approx 1.4 .^{68}$ The fact that the real pickup cross sections can be larger than the geometrical ones by a factor of more than 2 can have a pronounced effect in atmospheric aerosol modeling, where the geometrical cross sections are often considered. Finally, it should be noted that the evaluation of the pickup cross section required the assumption of sticking collisions and the total momentum transfer. These assumptions were justified for $\mathrm{H}_{2} \mathrm{O}$ molecules by our MD simulations; however, similar simulations would be needed for the other molecules picked up by the ice nanoparticles.

In the context of the aerosol nucleation, it is interesting to compare our pickup cross sections with the recent work of Signorell's group. ${ }^{136}$ Their Laval-nozzle experiments allowed determination of the monomer association rates $k_{1, N}$ for $\mathrm{H}_{2} \mathrm{O}$ molecules with water clusters of different sizes $N$. In their work, ${ }^{136} k_{1, N}$ for the clusters above the dimer up to $N=30$ were compared to the free molecular collision rates obtained assuming the geometrical cross section of spherical clusters. The measured association rates were 4-5 times larger than the collision rates. This was attributed to the long range forces, e.g., dipole-dipole interactions and dispersion forces. Although we cannot provide a direct quantitative comparison between the association rates and our pickup cross sections, there is a clear correlation between them, and the larger measured association rates qualitatively agree with our pickup cross sections being larger than the geometrical ones.

From another point of view, the uptake of water molecules on mass selected protonated water clusters was measured by Zamith et al. ${ }^{137-140}$ The mass-spectrometric experiments with the protonated clusters provided the advantage of the known single cluster size, and the sticking collisions could be determined from the mass spectra. On the other hand, they were limited to smaller clusters and somewhat higher collision energies. For their upper size limit of $N=250$, the measured pickup cross section was $\approx 800 \AA^{2}$. Comparison with our neutral $\left(\mathrm{H}_{2} \mathrm{O}\right)_{N}$ pickup cross section suggests that the charge on the clusters does not seem to increase the pickup cross section, which calls for theoretical simulations.

Despite an extensive effort in the atmospheric aerosol research, there are still many open questions concerning the new particle formation and aerosol growth. Nucleation theories rely on macroscopic properties and gas kinetic arguments. ${ }^{141-143}$ Classical nucleation theory (CNT), which represents the current benchmark, ${ }^{143}$ can provide reasonable water vapor nucleation rates in some cases; ${ }^{143-146}$ nevertheless, empirical corrections and modifications along with refined theories are implemented in some cases to account for the differences between the experimental results and CNT predictions. ${ }^{136,147,148}$ From the perspective of the molecularlevel approach, the nucleation starts with the individual molecules colliding and sticking to small clusters. Typically, hard sphere collision rates and geometrical cross sections are considered in the modeling. ${ }^{46,149,150}$ The experiments mentioned above demonstrate that the actual pickup cross sections can be significantly larger, and more realistic values should be utilized.

3.2.2 Mixed nitric acid-water clusters. Aerosol nucleation in the atmosphere often involves the hydrated acid clusters, especially the sulfuric acid, ${ }^{151-154}$ and also nitric acid in the stratosphere. ${ }^{155}$ A recent extension of our method for pickup cross section measurements to acid clusters could provide relevant data for the atmospheric aerosol nucleation models. We used the hydrated nitric acid clusters $\left(\mathrm{HNO}_{3}\right)_{M} \cdot\left(\mathrm{H}_{2} \mathrm{O}\right)_{N}$ as the model for a general hydrated acid cluster. ${ }^{72,156,157}$ The hydrated sulfuric acid clusters were investigated as well; ${ }^{57}$ nevertheless, they led to frequent nozzle clogging, and the pickup experiments have not been accomplished yet.

In the experiments with the large $\left(\mathrm{H}_{2} \mathrm{O}\right)_{N}$ clusters above, many collisions in the pickup cell led to multiple pickup and momentum transfer processes, and the dependence of the cluster velocity on the pickup pressure was measured. Here, the experimental method was modified. Relatively small $\left(\mathrm{HNO}_{3}\right)_{M} \cdot\left(\mathrm{H}_{2} \mathrm{O}\right)_{N}$ clusters with an average size of $\bar{M} \approx 2$ $\bar{N} \approx 6$ passed through the pickup gas at a fixed pressure, which was carefully controlled so that the clusters of mean size underwent only a few (about 3) collisions in the pickup cell. Under these conditions, we could distinguish two mass peak series in the mass spectra measured after the pickup of a molecule $\mathrm{X}$ : one corresponding to the pure protonated cluster fragments $\left(\mathrm{HNO}_{3}\right)_{m} \cdot\left(\mathrm{H}_{2} \mathrm{O}\right)_{n} \mathrm{H}^{+}$, and the other one corresponding to the fragments with the adsorbed molecules $\mathrm{X} \cdot\left(\mathrm{HNO}_{3}\right)_{m}$. $\left(\mathrm{H}_{2} \mathrm{O}\right)_{n} \mathrm{H}^{+}$. Both series had almost identical character and differed only by their intensities. This is illustrated for our test case of methanol, $\mathrm{X}=\mathrm{CH}_{3} \mathrm{OH}$, in Fig. 4. The top panel of Fig. 4a shows the spectrum of the pure $\left(\mathrm{HNO}_{3}\right)_{M} \cdot\left(\mathrm{H}_{2} \mathrm{O}\right)_{N}$ clusters analyzed elsewhere. ${ }^{51,72}$ The middle panel of Fig. $4 \mathrm{~b}$ shows the spectrum after the pickup of methanol. Clearly, new weaker series are observed in Fig. $4 \mathrm{~b}$ as indicated, which are analogous to $\left(\mathrm{HNO}_{3}\right)_{m} \cdot\left(\mathrm{H}_{2} \mathrm{O}\right)_{n} \mathrm{H}^{+}$fragment ions and shifted by the mass of 


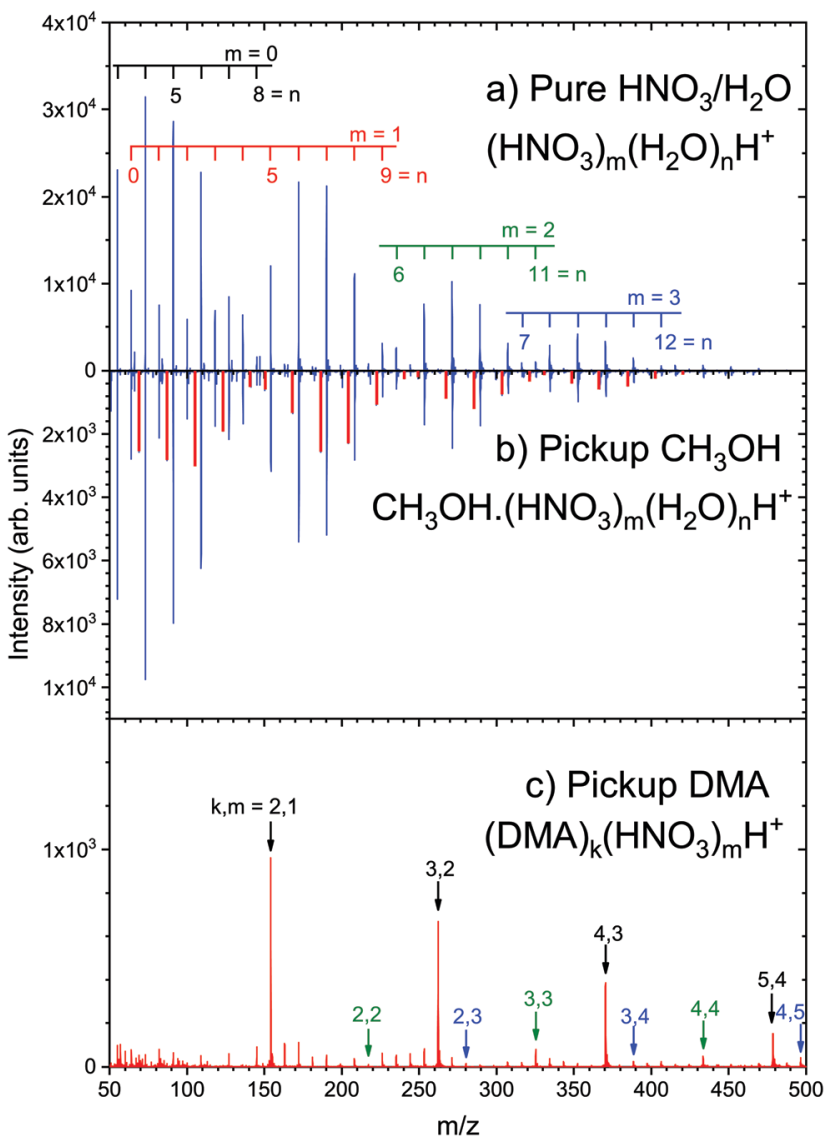

Fig. 4 Mass spectra showing the pickup of methanol $\left(\mathrm{CH}_{3} \mathrm{OH}\right)$ and dimethylamine $\left(\mathrm{CH}_{3}\right)_{2} \mathrm{NH}$ (DMA) on the mixed nitric acid-water clusters: (a) pure $\left(\mathrm{HNO}_{3}\right)_{M} \cdot\left(\mathrm{H}_{2} \mathrm{O}\right)_{N}$ clusters without the pickup; $\left(\mathrm{HNO}_{3}\right)_{m} \cdot\left(\mathrm{H}_{2} \mathrm{O}\right)_{n} \mathrm{H}^{+}$ series with different $m, n$ are labeled. ${ }^{51,72}$ (b) The pickup of methanol at a pickup pressure of about $4 \times 10^{-4}$ mbar results in the additional analogous $\mathrm{CH}_{3} \mathrm{OH} \cdot\left(\mathrm{HNO}_{3}\right)_{m} \cdot\left(\mathrm{H}_{2} \mathrm{O}\right)_{n} \mathrm{H}^{+}$series highlighted in red. ${ }^{158}$ The spectrum is plotted upside down for better comparison with the spectrum (a). (c) The spectrum after the DMA pickup at a pickup pressure of about $2 \times 10^{-3}$ mbar. The black arrows indicate the major series DMA.(DMA. $\left.\mathrm{HNO}_{3}\right)_{m} \mathrm{H}^{+}$. Further, less pronounced series $\left(\mathrm{DMA} \cdot \mathrm{HNO}_{3}\right)_{m} \mathrm{H}^{+}$and $\left(\mathrm{DMA} \cdot \mathrm{HNO}_{3}\right)_{m} \mathrm{H}-$ $\mathrm{NO}_{3} \mathrm{H}^{+}$are indicated by green and blue arrows, respectively.

methanol $\mathrm{m} / z=32$. By velocity measurements performed with the QMS tuned to different fragment ions, we could prove that $\left(\mathrm{HNO}_{3}\right)_{m} \cdot\left(\mathrm{H}_{2} \mathrm{O}\right)_{n} \mathrm{H}^{+}$fragments corresponded to the clusters which passed through the pickup cell without undergoing sticking collisions with $\mathrm{CH}_{3} \mathrm{OH}$. The velocities measured for the $\mathrm{CH}_{3} \mathrm{OH} \cdot\left(\mathrm{HNO}_{3}\right)_{m} \cdot\left(\mathrm{H}_{2} \mathrm{O}\right)_{n} \mathrm{H}^{+}$fragments were significantly lower than those of $\left(\mathrm{HNO}_{3}\right)_{m} \cdot\left(\mathrm{H}_{2} \mathrm{O}\right)_{n} \mathrm{H}^{+}$fragments. Clearly, the former fragments originated from the clusters which picked up the $\mathrm{CH}_{3} \mathrm{OH}$ molecule and were slowed down by the momentum transfer. The later velocities of $\left(\mathrm{HNO}_{3}\right)_{m} \cdot\left(\mathrm{H}_{2} \mathrm{O}\right)_{n} \mathrm{H}^{+}$fragments were shifted only very little to lower values with respect to the velocities measured without any methanol gas in the pickup cell. This small shift was attributed to non-sticking collisions of a grazing character. Therefore, we could assign the $\mathrm{CH}_{3} \mathrm{OH}$. $\left(\mathrm{HNO}_{3}\right)_{m} \cdot\left(\mathrm{H}_{2} \mathrm{O}\right)_{n} \mathrm{H}^{+}$and $\left(\mathrm{HNO}_{3}\right)_{m} \cdot\left(\mathrm{H}_{2} \mathrm{O}\right)_{n} \mathrm{H}^{+}$fragments to the clusters which underwent sticking and non-sticking collisions, respectively, and the pickup probability could be determined from the abundance ratio of the corresponding fragment series. The method was demonstrated for methanol pickup on $\left(\mathrm{HNO}_{3}\right)_{m} \cdot\left(\mathrm{H}_{2} \mathrm{O}\right)_{n} \mathrm{H}^{+}$clusters, ${ }^{158}$ and several other molecules $\mathrm{X}$ discussed below showed qualitatively the same behavior. ${ }^{159}$ These experiments represented the proof of concept for measuring the pickup probabilities, which can be useful for atmospheric aerosol modeling.

In atmospheric chemistry, bulk surface properties such as uptake coefficient $\gamma$ and surface (or mass) accommodation coefficient $\alpha_{\mathrm{S}}$ are generally used in the modeling of heterogeneous processes. ${ }^{160-163}$ These properties are usually determined in the experiments with macroscopic bulk surfaces. In such experiments, adsorption and desorption of the molecules from the surface, diffusion of the molecules from the surface into the bulk and their solubility in the bulk, and also chemical reactions have to be taken into account. In addition, the involved rates often change with time as the gas concentration gradient near the surface, as well as the concentration gradient in the bulk, changes. On the other hand, in our experiments, the clusters move through the pickup gas with extremely diluted concentration under high vacuum $\left(10^{-4} \mathrm{mbar}\right)$ undergoing just a few collisions within the pickup chamber. Thus, we can neglect any diffusion in the gas due to the gas concentration gradient near the cluster surface. No chemical reactions take place for the molecules discussed below on $\left(\mathrm{HNO}_{3}\right)_{M}$. $\left(\mathrm{H}_{2} \mathrm{O}\right)_{N}$ clusters, and the adsorbed molecules do not dissolve nor diffuse into the cluster interior due to the small size of the clusters. We are able to determine the fraction of the clusters to which the molecules stick upon collisions; therefore our pickup probability is purely a kinetic parameter disentangling the molecule pickup from its evaporation. Under these conditions the pickup probability corresponds to the surface accommodation coefficient $\alpha_{S}$. Thus our experiments provide a unique and direct way to determine experimentally $\alpha_{\mathrm{S}}$ for the investigated molecules on the proxies of ultrafine aerosol particles.

Now, with the method established, ${ }^{158}$ we can investigate the uptake of other atmospheric molecules. The volatile organic compounds (VOCs) belong to the key components in the aerosol generation. ${ }^{164-168}$ Therefore we have investigated the pickup of different VOCs and their oxidation products on $\left(\mathrm{HNO}_{3}\right)_{M} \cdot\left(\mathrm{H}_{2} \mathrm{O}\right)_{N}$ clusters. ${ }^{159}$ The pickup of isoprene, $\alpha$-pinene, 2-methyl-3-buten-2-ol, 3-methyl-3-buten-1-ol and verbenone was studied. The experiments delivered the $\alpha_{\mathrm{S}}$ coefficients, which can be used for atmospheric aerosol modeling, and demonstrated that the oxidation increases the surface accommodation of VOCs by more than an order of magnitude. Accompanying theoretical calculations justified the experimental findings by forming of hydrogen bonds between the oxidized compounds and the clusters, whereas the interactions of the parent VOCs with the clusters were weaker and nonspecific. $^{159}$

Bases, e.g., ammonia and amines, contribute strongly to the aerosol nucleation as well. ${ }^{46,142,169}$ Therefore we picked up dimethylamine, $\left(\mathrm{CH}_{3}\right)_{2} \mathrm{NH}$ (DMA), on the hydrated acid clusters. However, a completely different mass spectrum was encountered (Fig. 4c). It is strongly dominated by a single 
series, which could be assigned to the DMA $\left(\text { DMA. } \mathrm{HNO}_{3}\right)_{m} \mathrm{H}^{+}$ ions. This suggests the acid-base reaction between $\mathrm{HNO}_{3}$ and DMA leading to proton transfer and generating the ion pair $\mathrm{NO}_{3}{ }^{-} \cdots$ DMA $\cdot \mathrm{H}^{+}$. The energy released in the acid-base reactions leads to water evaporation from the clusters, since the anhydrous DMA.(DMA. $\left.\mathrm{HNO}_{3}\right)_{m} \mathrm{H}^{+}$ions dominate the mass spectrum. The water evaporation is in line with recent investigation of nanoparticle formation and growth from dimethylamine and nitric acid, ${ }^{170}$ where relatively low binding energies of water molecules in these neutral clusters were calculated. There are also weaker mass peaks corresponding to the (DMA. $\left.\mathrm{HNO}_{3}\right)_{m} \mathrm{H}^{+}$and $\left(\mathrm{DMA} \cdot \mathrm{HNO}_{3}\right)_{m} \mathrm{HNO}_{3} \mathrm{H}^{+}$series in Fig. $4 \mathrm{c}$ indicated by the green and blue arrows, respectively. These series are also consistent with the assumption of the acid-base reaction and (DMAH) ${ }^{+} \cdots \mathrm{NO}_{3}{ }^{-}$ion pair generation.

It should be noted that the above assignment is not unambiguous due to the mass coincidences between various (DMA) ${ }_{k}$. $\left(\mathrm{HNO}_{3}\right)_{m} \cdot\left(\mathrm{H}_{2} \mathrm{O}\right)_{n} \mathrm{H}^{+}$fragments with different number of DMA, $\mathrm{HNO}_{3}$ and $\mathrm{H}_{2} \mathrm{O}$ molecules. In principle, this could be resolved by high-resolution measurements. We have demonstrated previously $^{72}$ that the resolution of $M / \Delta M \approx 4 \times 10^{3}$ could be achieved with our RTOF allowing a clear separation of protonated water heptamer $\left(\mathrm{H}_{2} \mathrm{O}\right)_{7} \mathrm{H}^{+}$and nitric acid dimer $\left(\mathrm{HNO}_{3}\right)_{2} \mathrm{H}^{+}$peaks in the mass spectra. However, the separation of, e.g., protonated water hexamer $\left(\mathrm{H}_{2} \mathrm{O}\right)_{6} \mathrm{H}^{+}$from nitric acidDMA complex $\mathrm{HNO}_{3} \cdot \mathrm{DMA} \cdot \mathrm{H}^{+}$would require even much higher mass resolution. Nevertheless, the present assignment is the most straightforward one, based on the acid-base reaction. There are still many open questions, for example: Does the acid-base reaction and subsequent water evaporation happen in the neutral cluster, or only after the ionization process? The presence of mainly anhydrous clusters in the spectrum supports the former scenario, since complete water evaporation is not observed upon ionization of the pure $\left(\mathrm{HNO}_{3}\right)_{M} \cdot\left(\mathrm{H}_{2} \mathrm{O}\right)_{N}$ clusters (Fig. 4a). However, such questions can be addressed and clarified by theoretical calculations and further experiments which are currently performed.

Similar experiments might be useful for the interpretation of the mass spectra measured in aerosol chambers, such as the Cosmics Leaving Outdoor Droplets (CLOUD) experiment. ${ }^{47} \mathrm{~A}$ significant increase of the aerosol nucleation was observed in the presence of ammonia ${ }^{169,171}$ and $\mathrm{DMA}^{172}$ in the CLOUD experiments. In those experiments, all aerosol nucleation precursors are added into the system (acid, base, water, ionizing radiation, etc.), and the mass spectra are recorded varying the conditions. In the CLUB experiments, we start with relatively well-defined hydrated acid clusters, on which the amine molecules are picked up. Thus, we can investigate the processes step by step providing complementary information to the CLOUD experiments, where the final results of more complex processes are monitored. For example, we can clearly see the water evaporation upon DMA and $\mathrm{HNO}_{3}$ reactions in our cluster experiments.

\subsection{Clusters for interstellar chemistry}

Despite the seemingly hostile conditions for chemistry in space, more than 200 molecules have been identified in the interstellar medium (ISM), among them some quite large and complex ones such as amino acids and polycyclic aromatic hydrocarbons (PAHs). ${ }^{173}$ How are these molecules formed in the ISM? Low densities of molecules, which in the densest regions of the giant molecular clouds hardly exceed $10^{6} \mathrm{~cm}^{-3}$ (some 13 orders of magnitude less than the air in the Earth's atmosphere), imply infrequent collisions. Low temperatures, typically $\sim 10-100 \mathrm{~K}$, often do not allow to surmount reaction barriers. However, there are other chemical pathways prevailing in the ISM, e.g., surface-catalyzed reactions or radical and ion-molecule reactions, which are essentially barrierless. ${ }^{39-41,174,175}$ The ISM contains dust/ice grains acting as "sponges", where the molecules can be adsorbed and stored for a long time, and eventually interact and react spontaneously or the reactions can be triggered by radiation. To simulate the dust/ice catalyzed chemistry, usually bulk surfaces are employed in the laboratory studies. ${ }^{176-178}$

The clusters and nanoparticles in molecular beams can provide an alternative approach. They can mimic the dust/ice grains and offer some advantages for understanding the surface catalyzed chemistry. For example, the reaction intermediates and even the final products are sometimes difficult to detect in the bulk system. ${ }^{177}$ In the case of clusters, they often leave the finite-size cluster and can be detected and characterized by mass spectrometry or optical spectroscopy. Thus the clusters can offer a detailed insight into the individual steps of complex reactions on dust/ice grains.

The ice nanoparticles investigated in our experiments can represent a model system for the water-ice covered grains in the ISM. Quite common in the ISM are various carbonaceous dust particles. ${ }^{179}$ Also PAHs and their clusters have been suggested to be implemented in the ISM molecule synthesis. ${ }^{180,181}$ The PAH clusters have already been investigated experimentally by different methods, e.g., IR and UV spectroscopy ${ }^{182}$ mass spectrometry, ${ }^{183,184}$ collisions with energetic ions, ${ }^{185-187}$ photoelectron spectroscopy, ${ }^{188,189}$ and in He-nanodroplets. ${ }^{190} \mathrm{We}$ have started to investigate the pickup of molecules by the carbonaceous and PAH clusters.

The mixed clusters of PAHs with other molecules were produced by other than pickup techniques in numerous studies. For example benzene-water ${ }^{191,192}$ and naphthalenewater $^{193,194}$ cluster cations were generated by solvation of $\mathrm{PAH}$ cations in collision with water. The naphthalene-water clusters were also produced by co-expansion of naphthalene with water vapor in argon carrier gas, and subsequently ionized by vacuum ultraviolet photoionization. ${ }^{195}$ In connection with our experiments on adamantane (AD) discussed below, we should mention also the spectroscopy of the ions formed by electron ionization of adamantane ${ }^{196}$ and the adamantanewater cluster cation. ${ }^{197}$

Here, we present one of our first investigations, the pickup of methanol, which can be quite abundant in the ISM, on adamantane clusters $(\mathrm{AD})_{N}$ as a prerequisite for the future investigations of chemical reactions of molecules adsorbed on such carbonaceous clusters. Fig. 5 shows the corresponding mass spectrum. The dominating cluster ion series $(\mathrm{AD})_{n}{ }^{+}$is 


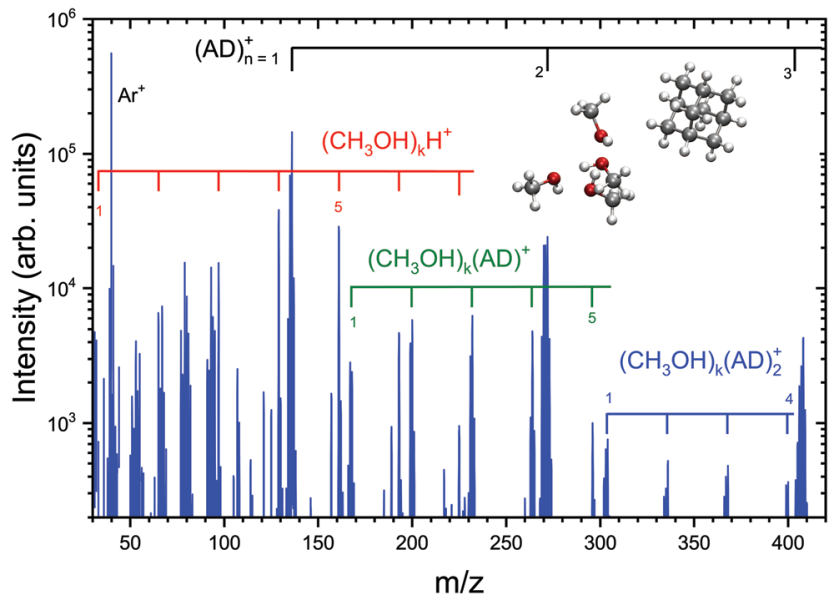

Fig. 5 Mass spectrum of adamantane $(A D)_{N}$ clusters after the methanol pickup showing the $(A D)_{n}{ }^{+}$cluster fragment series together with the $\left(\mathrm{CH}_{3} \mathrm{OH}\right)_{k} \mathrm{H}^{+},\left(\mathrm{CH}_{3} \mathrm{OH}\right)_{k}(\mathrm{AD})^{+}$and $\left(\mathrm{CH}_{3} \mathrm{OH}\right)_{k}(\mathrm{AD})_{2}{ }^{+}$series. The inset shows a structure of the $\mathrm{AD}$ complex with 4 methanol molecules for illustration.

indicated together with clear methanol containing series $\left(\mathrm{CH}_{3} \mathrm{OH}\right)_{k} \mathrm{H}^{+}$and $\left(\mathrm{CH}_{3} \mathrm{OH}\right)_{k}(\mathrm{AD})_{n}{ }^{+}, n=1$, 2. Each mass peak is accompanied by satellites with different number of $\mathrm{H}$ atoms; nevertheless, the major observations can be summarized: adamantane clusters are generated, and several methanol molecules can be adsorbed on $(\mathrm{AD})_{N}$ in the pickup cell and coagulate to $\left(\mathrm{CH}_{3} \mathrm{OH}\right)_{K}$ clusters with $K \geq 7$. An interesting observation is that the protonated $\left(\mathrm{CH}_{3} \mathrm{OH}\right)_{k} \mathrm{H}^{+}$fragments are ejected from the clusters after the ionization. The protonated cluster fragments are typical for the hydrogen bonded clusters such as methanol or water in the gas phase. On the other hand, if the methanol clusters stick to one or two $\mathrm{AD}$ molecules after the ionization, the major peaks correspond to $\left(\mathrm{CH}_{3} \mathrm{OH}\right)_{k}(\mathrm{AD})_{n}{ }^{+}$ions, i.e., nonprotonated clusters. Theoretical investigation can help to investigate the structure of these clusters.

\subsection{Coagulation of molecules on clusters}

So far, we have concentrated on the uptake process of the molecule by the cluster. The next logical question is: What happens with the molecules adsorbed on the cluster? Do they migrate on the cluster surface or remain bound to a spot? Do they stay on the surface or submerge into the cluster interior? These questions were addressed previously in some cases. ${ }^{22}$ For example, the surface mobility of barium atoms and various molecules and generation of their clusters within large argon clusters was observed. ${ }^{24,198}$ In another spectroscopic experiment, methanol clusters were coagulated from individually adsorbed molecules on argon clusters. ${ }^{94}$ In helium nanodroplets, complexes of picked up molecules were generated. ${ }^{16-18,21,83,88,89,91,199}$ However, rare gas clusters, and especially helium, represent rather special cases, and here we concentrate on the molecular clusters such as the ice nanoparticles.

We addressed the questions of migration and coagulation of molecules on/in clusters ${ }^{200}$ picking up different atmospherically relevant molecules $\mathrm{X}\left(\mathrm{X}=\mathrm{HCl}, \mathrm{CH}_{4}, \mathrm{CH}_{3} \mathrm{Cl}_{1} \mathrm{CH}_{3} \mathrm{CH}_{2} \mathrm{CH}_{2} \mathrm{Cl}\right.$, chlorobenzene, and benzene) on $\mathrm{Ar}_{N}$ and $\left(\mathrm{H}_{2} \mathrm{O}\right)_{N}$ clusters with the mean sizes $\bar{N} \approx 330$ and 430 , respectively, corresponding to approximately the same geometrical cross sections. The clusters underwent multiple pickup collisions with the molecules. In the case of $\mathrm{Ar}_{N}$, the electron ionization mass spectra exhibited $\mathrm{X}_{k}^{+}$ion fragments up to $k \approx 10$ for most molecules. For methane, which did not stick to $\mathrm{Ar}_{N}$ easily, and is not prone to clustering, $\mathrm{CH}_{4}$ complexes up to the trimer were observed.

On the other hand, there was no evidence for cluster formation on $\left(\mathrm{H}_{2} \mathrm{O}\right)_{N}$ for the above molecules. This was not caused by the lack of adsorption of the molecules on $\left(\mathrm{H}_{2} \mathrm{O}\right)_{N}$. The nanoparticles were slowed down by the momentum transfer, and individual molecules $X$ could be seen in the mass spectra arriving with the ice nanoparticles into the mass spectrometer. In some cases, also the photodissociation experiments (discussed in Section 4.1) proved the presence of the molecules on $\left(\mathrm{H}_{2} \mathrm{O}\right)_{N} \cdot{ }^{62}$ Thus we could conclude that the above molecules coagulated to $\mathrm{X}_{K}$ clusters on $\mathrm{Ar}_{N}$, while they remained isolated on $\left(\mathrm{H}_{2} \mathrm{O}\right)_{N}$ during the flight time of about 1 ms from the pickup cell to the RTOF.

Accompanying theoretical MD simulations justified our findings: the molecules coagulated on $\mathrm{Ar}_{N}$ while they mostly remained bound where they landed on ice nanoparticles. The simulations also suggested that the molecules partly submerged in the cluster surface on $\mathrm{Ar}_{N}$, despite the low temperature of the cluster of about $30-40 \mathrm{~K}$ and thus its solid-like nature. ${ }^{115}$ In the case of the ice nanoparticles the molecules remained bound to the surface. In another experiment, we adsorbed Freon $\mathrm{CF}_{2} \mathrm{Cl}_{2}$ molecules on $\mathrm{Ar}_{N}$ and ice nanoparticles, ${ }^{63}$ and we observed the same pattern: coagulation to $\left(\mathrm{CF}_{2} \mathrm{Cl}_{2}\right)_{K}$ clusters on $\mathrm{Ar}_{N}$ and pickup but no coagulation on $\left(\mathrm{H}_{2} \mathrm{O}\right)_{N}$.

Yet another interesting example of the difference between the coagulation of molecules picked up on $\operatorname{Ar}_{N}$ and $\left(\mathrm{H}_{2} \mathrm{O}\right)_{N}$ can be found in our recent study of the hydrogen peroxide $\left(\mathrm{H}_{2} \mathrm{O}_{2}\right)$ pickup and reactions on these clusters. ${ }^{66}$ The top panel of Fig. 6a shows the electron ionization mass spectrum of the

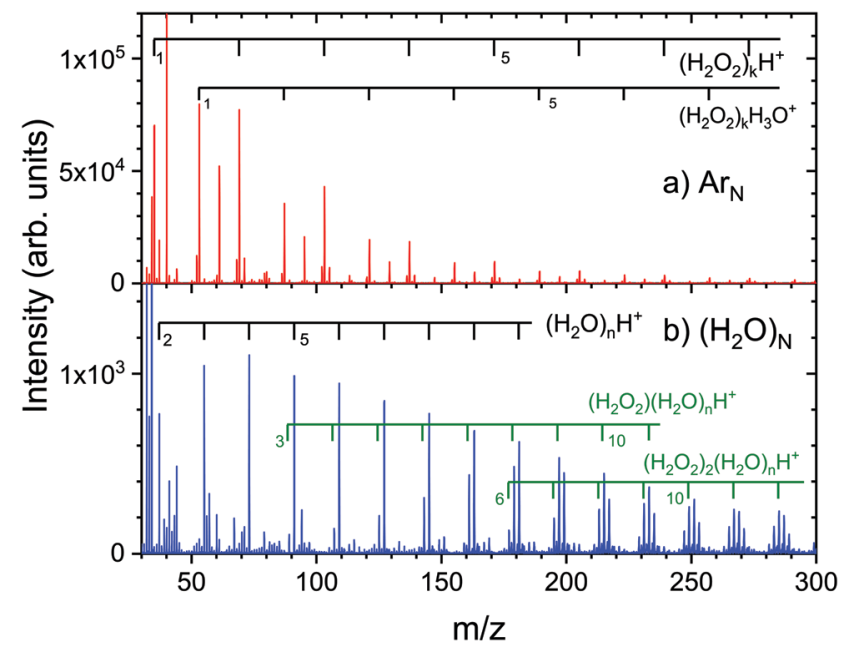

Fig. 6 Mass spectra of $\mathrm{H}_{2} \mathrm{O}_{2}$ molecules picked up on (a) $\operatorname{Ar}_{N}, \bar{N} \approx 160$, and $(b)\left(\mathrm{H}_{2} \mathrm{O}\right)_{N}, \bar{N} \approx 120$. The major fragment ion series are indicated and discussed in the text. 
clusters generated after the pickup on $\operatorname{Ar}_{N}, \bar{N} \approx 160$. The spectrum exhibits several fragment ion series containing $\mathrm{H}_{2} \mathrm{O}_{2}$ clusters. We label the major series corresponding to the protonated hydrogen peroxide $\left(\mathrm{H}_{2} \mathrm{O}_{2}\right)_{k} \mathrm{H}^{+}$(further series and their discussion can be found in our recent publication ${ }^{66}$ ). Fragments with up to $k=20 \mathrm{H}_{2} \mathrm{O}_{2}$ molecules could be identified in the spectrum upon detailed analysis.

Fig. $6 \mathrm{~b}$ shows the spectrum after the pickup of $\mathrm{H}_{2} \mathrm{O}_{2}$ on $\left(\mathrm{H}_{2} \mathrm{O}\right)_{N}, \bar{N} \approx 120$. Here, the spectrum is dominated by the protonated water $\left(\mathrm{H}_{2} \mathrm{O}\right)_{n} \mathrm{H}^{+}$; nevertheless, it contains also the series with $\mathrm{H}_{2} \mathrm{O}_{2}$ molecules, $\left(\mathrm{H}_{2} \mathrm{O}_{2}\right)_{k} \cdot\left(\mathrm{H}_{2} \mathrm{O}\right)_{n} \mathrm{H}^{+}$, with $k$ up to $8\left(k=1\right.$ and 2 are labeled in Fig. 6b). Clearly, multiple $\mathrm{H}_{2} \mathrm{O}_{2}$ molecules could be adsorbed on the ice nanoparticles; however, there are no anhydrous cluster ion fragments $\left(\mathrm{H}_{2} \mathrm{O}_{2}\right)_{k} \mathrm{H}^{+}$. For the $\left(\mathrm{H}_{2} \mathrm{O}_{2}\right)_{k} \cdot\left(\mathrm{H}_{2} \mathrm{O}\right)_{n} \mathrm{H}^{+}$series, we find that each $k$ number of $\mathrm{H}_{2} \mathrm{O}_{2}$ molecules is accompanied by $n>k$ water molecules, and the maximum of each series corresponds to the fragment composition with many more water molecules than $\mathrm{H}_{2} \mathrm{O}_{2}$ molecules, $n \gg k$. This suggests that the $\mathrm{H}_{2} \mathrm{O}_{2}$ molecules do not coagulate to $\left(\mathrm{H}_{2} \mathrm{O}_{2}\right)_{K}$ clusters on $\left(\mathrm{H}_{2} \mathrm{O}\right)_{N}$, just that the electron ionization generates the protonated water fragments and some $\mathrm{H}_{2} \mathrm{O}_{2}$ molecules remain attached. However, this hypothesis needs further experimental and theoretical verification.

Apparently, all the picked up molecules, discussed so far, coagulated on $\mathrm{Ar}_{N}$, but were immobilized on $\left(\mathrm{H}_{2} \mathrm{O}\right)_{N}$. Is this a general pattern? It turns out that we had evidence for molecules coagulating on the ice nanoparticles as well. The first example was represented by 2-hydroxypyridine (HP). ${ }^{74}$ These molecules generated large clusters on $\mathrm{Ar}_{N}$, but we found the evidence for generation of $(\mathrm{HP})_{K}$ clusters with $K$ up to 8 also on $\left(\mathrm{H}_{2} \mathrm{O}\right)_{N}$. It is worth noting that these molecules showed a strong propensity for dimer formation on $\left(\mathrm{H}_{2} \mathrm{O}\right)_{N}$. Accompanying calculations showed that the dimers exhibited hydrogen bonds analogous to the base pairing in DNA. Thus this result can contribute to the discussion of the biomolecule synthesis on the ice grains in the space. ${ }^{40,174,201-203}$ Similarly, we observed coagulation of uracil and 5-bromouracil on $\left(\mathrm{H}_{2} \mathrm{O}\right)_{N} \cdot{ }^{204}$ Thus the observed propensity for aggregation on ice nanoparticles seems to be a more general trend for molecules forming strong hydrogen bonds among themselves, e.g., biomolecular analogues. Recently, we have observed also pyruvic and valeric acid coagulating on $\left(\mathrm{H}_{2} \mathrm{O}\right)_{N \cdot}{ }^{205,206}$ Table 1 provides the overview of molecules picked up on different clusters within our investigations, and indicates whether the molecules coagulated to clusters or not by labels $\mathrm{c}$ or $x$, respectively. Theoretical investigations could elucidate the interplay of forces acting between the molecules on nanoparticles, which lead to their mobility and coagulation.

\section{Reactions triggered by photons and electrons}

So far, we have focused on the pickup of molecules by the clusters. Now, we will discuss reactions between the adsorbed molecules. The reactions between neutral ground-state molecules were observed in some special cases previously, e.g., the reactions of $\mathrm{Ba}$ atoms with different molecules mentioned in the introduction..$^{23-29}$ We provide some evidence for the acidbase reaction between $\mathrm{HNO}_{3}$ and DMA in Section 3.2.2. However, in this section, we concentrate on the reactions triggered by photons or electrons. In Table 1 we indicate for all the picked up molecules whether we have observed reactions after the electron ionization $\mathrm{i}^{+}$, or photon excitation-ionization $h \nu$, or slow electron attachment $\mathrm{e}^{-}$.

\subsection{Photodissociation of molecules on clusters}

The photodissociation of a molecule is sometimes referred to as the half-reaction, and in that sense it can be regarded as one

Table 1 Overview of different molecules picked up on different clusters and processes observed in this review. Investigated processes: $c-c o a g u l a t i o n$ of molecules on/in the cluster, $x$ - non-coagulation, $\sigma_{\mathrm{pu}}$ - pickup cross section, $\alpha_{\mathrm{S}}$ - surface accommodation coefficient, $\mathrm{i}^{+}-$reactions after electron ionization, $h \nu$ - reactions after UV photon excitation/ionization, $\mathrm{e}^{-}-$electron attachment and negative ion reactions

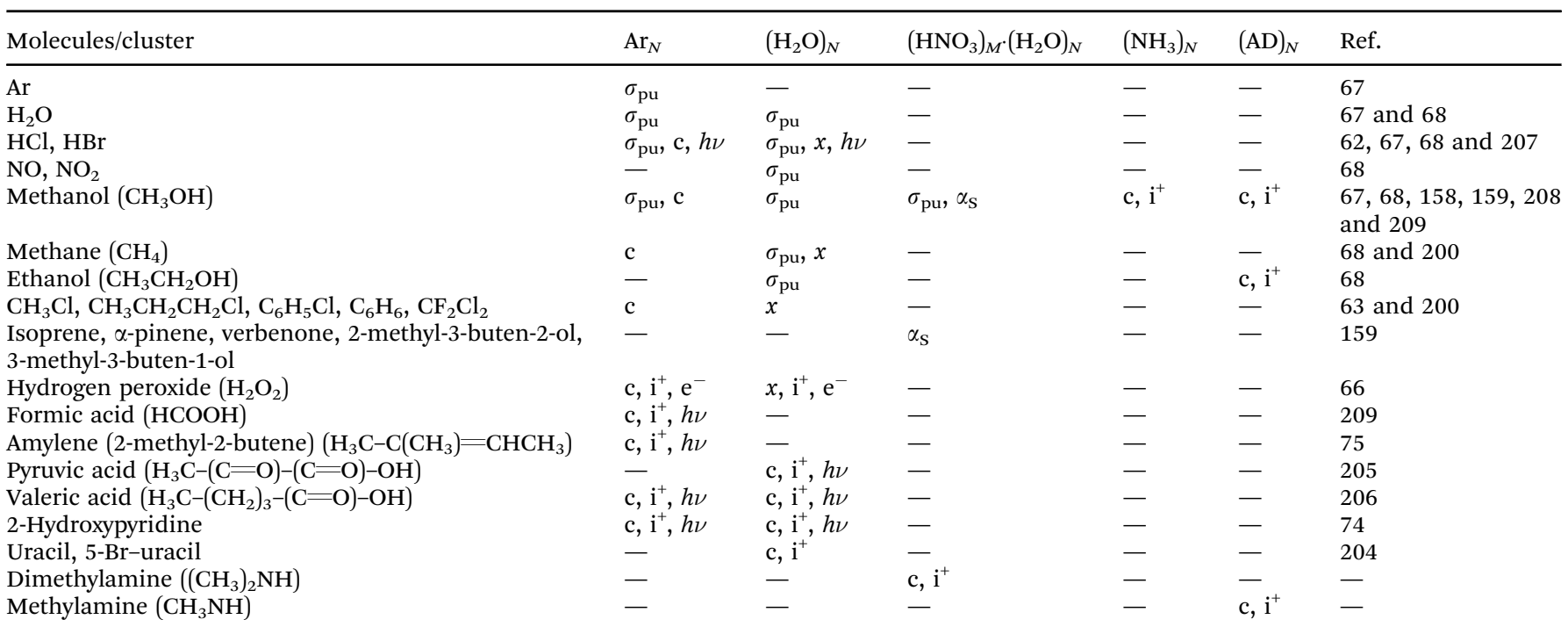


of the simplest chemical reactions. ${ }^{210,211}$ The effect of a solvent on the photodissociation is of prime importance for understanding the chemistry in bulk systems irradiated by UV photons. ${ }^{212,213}$ With this motivation the photodissociation of molecules in rare gas clusters was investigated. ${ }^{22,36,37,214}$

Although the rare gas clusters represented a benchmark system emulating a weakly interacting environment, let us concentrate on the atmospherically more relevant systems such as the large water clusters $\left(\mathrm{H}_{2} \mathrm{O}\right)_{N}$. They can mimic the ice particles in the polar stratospheric clouds (PSCs). Type II PSCs are composed essentially of pure water ice. ${ }^{155}$ The PSC particles represent the key players in the chemistry leading to the Antarctic ozone hole. ${ }^{155,215-218}$ The heterogeneous chemistry on their surfaces converts so called reservoir species $(\mathrm{HCl}$, $\left.\mathrm{ClONO}_{2}\right)$ to the active ones $\left(\mathrm{Cl}_{2}, \mathrm{HOCl}\right)$, which can be readily photolyzed by the sun radiation yielding the ozone destroying $\mathrm{Cl}^{\bullet}$ and other radicals. The reservoir species originate from the photolysis of the Cl-containing molecules in the stratosphere such as the infamous Freon $\mathrm{CF}_{2} \mathrm{Cl}_{2}$, and subsequent $\mathrm{Cl}^{\circ}$ reactions with other atmospheric molecules, e.g., reactions with $\mathrm{CH}_{4}$ produce $\mathrm{HCl}$.

We have investigated the photodissociation of hydrogen halides $\mathrm{HX}(\mathrm{X}=\mathrm{Cl}, \mathrm{Br})$ on $\left(\mathrm{H}_{2} \mathrm{O}\right)_{N}$ implementing also $\mathrm{Ar}_{N}$ for comparison. ${ }^{62}$ The molecules adsorbed on the $\mathrm{Ar}_{N}$ clusters formed $(\mathrm{HX})_{K}$ clusters, as revealed above, and the $\mathrm{H}$ fragments underwent caging after the photodissociation yielding the fragments with essentially zero kinetic energy. The heavy $\mathrm{Cl}^{\bullet}$ fragments were also caged; however, some of them escaped the cluster without losing their kinetic energy. On $\left(\mathrm{H}_{2} \mathrm{O}\right)_{N}$ clusters, the HX molecules did not coagulate and remained isolated, and their (photo)chemistry was quite different. First, the acidic dissociation occurred on $\left(\mathrm{H}_{2} \mathrm{O}\right)_{N}$ already in the ground state generating the $\mathrm{H}_{3} \mathrm{O}^{+} \cdots \mathrm{X}^{-}$ion pair. This ion pair was then excited by the UV photon yielding a neutral hydronium radical $\mathrm{H}_{3} \mathrm{O}^{\bullet} \cdot{ }^{219-223} \mathrm{H}_{3} \mathrm{O}^{\bullet}$ was metastable and quickly decayed yielding the observed $\mathrm{H}^{\bullet}$ fragments with low kinetic energy. This reaction pathway was observed in previous photodissociation studies, ${ }^{207,224,225}$ and also confirmed theoretically. ${ }^{219,220,226}$ The corresponding $\mathrm{Cl}^{\bullet}$ fragment was trapped in the ice nanoparticles. Possible relevance of such photodissociation of $\mathrm{HCl}$ on the PSC particles was discussed. ${ }^{62,224}$ The acidic dissociation enhances the $\mathrm{HCl}$ photolysis rate in the $200-300 \mathrm{~nm}$ region by about four orders of magnitude. ${ }^{224}$ On the other hand, this enhancement of the $\mathrm{Cl}^{\bullet}$ radical yield from $\mathrm{HCl}$ on the ice could be counterbalanced by the trapping of the $\mathrm{Cl}^{\bullet}$ in the particles. ${ }^{62}$

The photodissociation of Freon $\mathrm{CF}_{2} \mathrm{Cl}_{2}$ was investigated in pure $\left(\mathrm{CF}_{2} \mathrm{Cl}_{2}\right)_{N}$ clusters and also when adsorbed on $\mathrm{Ar}_{N}$ and $\left(\mathrm{H}_{2} \mathrm{O}\right)_{N}$ clusters, ${ }^{63}$ as well as a single $\mathrm{CF}_{2} \mathrm{Cl}_{2}$ molecule embedded inside $\mathrm{Ar}$ and Xe clusters. ${ }^{227}$ The general feature of the photodissociation process was the caging of $\mathrm{Cl}^{\bullet}$ observed in all kinds of clusters. However, the $\mathrm{Cl}^{-}$fragments from $\mathrm{Ar}_{N}$ clusters were detected, which meant that the fragments were slowed down to near-zero kinetic energies, but they still exit the cluster or the cluster decayed upon the photodissociation process. On the other hand, no $\mathrm{Cl}^{\bullet}$ fragments from $\left(\mathrm{H}_{2} \mathrm{O}\right)_{N}$ were detected, despite the clear evidence for the uptake of $\mathrm{CF}_{2} \mathrm{Cl}_{2}$ on $\left(\mathrm{H}_{2} \mathrm{O}\right)_{N}$. The loss of $\mathrm{Cl}^{\bullet}$ can be atmospherically important. The $\mathrm{Cl}^{\bullet}$ fragments trapped in the ice nanoparticle after the photodissociation can be washed out from the atmosphere. The accompanying theoretical calculations rationalized this observation by the formation of halogen bonds, where the $\mathrm{Cl}$ atoms of $\mathrm{CF}_{2} \mathrm{Cl}_{2}$ pointed to the oxygen of the water molecules in the nanoparticle. MD simulations of the dissociation process showed that the $\mathrm{Cl}^{\bullet}$ entered the cluster after the photodissociation, and remained trapped. ${ }^{63}$

\subsection{Reactions after excitation and ionization}

The clusters represent a very special environment for reactions of molecules in the excited or ionized states, and the reaction pathways can differ from the reactions in both the gas and the condensed phases. In clusters, the reactants are in direct contact already before they are excited or ionized. Thus the collision process, preceding a reaction in the gas phase, is absent in the cluster, and the reaction can readily proceed at a kinetic rate. The interaction potentials can be altered by the cluster environment, and reaction pathways different from the gas phase can be followed. The cluster can lead to the product caging as discussed above for the photodissociation processes. The cluster can serve as an efficient heat bath with many closely spaced degrees of freedom, where excited states can be efficiently quenched. On the other hand, in comparison with the condensed phase, the clusters provide a much simpler environment allowing molecular-level understanding of the investigated reactions. The energy released in the reaction leads to the cluster decay and the reaction products, which are usually trapped in the bulk, can be released from the cluster and detected. Thus, reaction intermediates can be observed, such as activated complexes and radicals, which usually react immediately in the bulk. All these aspects are well known and have been discussed in numerous studies. ${ }^{3,4,22,43,53,55,104,113,228}$

We have investigated quite a few systems where the molecules were picked up on different clusters and reactions were subsequently triggered by interaction with electrons (typically of $70 \mathrm{eV}$ ) and/or photons (usually at $193 \mathrm{~nm}, 6.4 \mathrm{eV}$ ). For example, the reactions of amylene (2-methyl-2-butene, $\mathrm{H}_{3} \mathrm{C}-$ $\left.\mathrm{C}\left(\mathrm{CH}_{3}\right)=\mathrm{CH}-\mathrm{CH}_{3}\right)$ molecules picked up on $\mathrm{Ar}_{N}$ have been observed recently. ${ }^{75}$ The mass spectra after the electron ionization and photoionization exhibited striking differences pointing to the excited state reactions, which occurred only during the photoionization process. From the perspective of atmospheric chemistry, small carboxylic acids play an important role in the secondary organic aerosol formation. ${ }^{46,229-231}$ We have investigated valeric acid $\left(\mathrm{H}_{3} \mathrm{C}-\left(\mathrm{CH}_{2}\right)_{3}-(\mathrm{C}=\mathrm{O})-\mathrm{OH}\right)$ and pyruvic acid $\left(\mathrm{H}_{3} \mathrm{C}-(\mathrm{C}=\mathrm{O})-(\mathrm{C}=\mathrm{O})-\mathrm{OH}\right)$ in clusters and picked up on $\left(\mathrm{H}_{2} \mathrm{O}\right)_{N}$ and $\mathrm{Ar}_{N}$ clusters. ${ }^{205,206}$ From the perspective of the interstellar chemistry, ammonia and methanol together with water represent the primary hydrogen-bonding molecules detected in the interstellar clouds, ices and comets in high abundance. ${ }^{232-236}$ We have studied the uptake and ionization of methanol on large ammonia $\left(\mathrm{NH}_{3}\right)_{N}, \bar{N} \approx 230$, clusters. ${ }^{208}$ However, we are not discussing these experiments in more 
detail and the interested reader is referred to the above references.

Our ultimate goal was to observe a reaction between two different molecules adsorbed on a cluster. This has recently been achieved for methanol $\left(\mathrm{CH}_{3} \mathrm{OH}\right)$ and formic acid (HCOOH) adsorbed on $\mathrm{Ar}_{N}$ nanoparticles. ${ }^{209} \mathrm{The} \mathrm{Ar}_{N}$ nanoparticles picked up the molecules in two sequential pickup cells in SC and PC chambers (see Fig. 2). We probed the clusters by photon and electron ionization yielding very similar spectra in this case. When only one kind of molecules was adsorbed on $\mathrm{Ar}_{N}$, the spectra revealed protonated clusters of either $\left(\mathrm{CH}_{3} \mathrm{OH}\right)_{m} \mathrm{H}^{+}$or $(\mathrm{HCOOH})_{m} \mathrm{H}^{+}$. When both molecules were adsorbed on the nanoparticles, mixed clusters appeared as well. We used isotopically labeled molecules to prove the reactions between $\mathrm{CH}_{3} \mathrm{OH}$ and $\mathrm{HCOOH}$. Perdeuterated methanol $\left(\mathrm{CD}_{3} \mathrm{OD}\right)$ demonstrated the deuteron transfer reactions to formic acid resulting in $(\mathrm{HCOOH})_{m} \mathrm{D}^{+}$cluster ions, as well as the proton transfer from formic acid resulting in $\left(\mathrm{CD}_{3} \mathrm{OD}\right)_{m} \mathrm{H}^{+}$. The latter process was expected for the acidic molecule, while the former reaction was, perhaps, less intuitive. The experiments with the partially deuterated methanol $\mathrm{CD}_{3} \mathrm{OH}$ and $\mathrm{CH}_{3} \mathrm{OD}$ further revealed the proton transfer from both methyl and hydroxyl groups. These findings were supported by ab initio calculations. ${ }^{209}$ Both molecules $\mathrm{CH}_{3} \mathrm{OH}$ and $\mathrm{HCOOH}$ are abundant in the ISM, and the methoxy radical $\mathrm{CH}_{3} \mathrm{O}^{\bullet}$ and the hydromethoxy radical $\mathrm{CH}_{2} \mathrm{OH}^{\bullet}$ were implemented in the formation of complex organic molecules in astrochemistry. ${ }^{237-240}$ Our study shows that such radicals might be generated in the proton transfer processes on the grains and released from them. More realistic proxies of interstellar grains will be used in future experiments, e.g., the carbonaceous clusters discussed in Section 3.3.

\subsection{Electron attachment}

Another area of reactions on free clusters is the electron attachment and negative ion reactions. The dissociative electron attachment (DEA) of isolated molecules is important in many areas of physics and chemistry, as reviewed recently by Fabrikant et al. ${ }^{241}$ Indeed, the question, how does a more complex environment of clusters influence the DEA process, has been ever-present already in the early studies. ${ }^{242,243} \mathrm{~A}$ recent review covered several fundamental effects of the environment on the DEA process in clusters, which can lead to an enhancement as well as to a suppression of the electron attachment cross section. ${ }^{244}$

In relevance to the atmospheric aerosols discussed above, we have concentrated on the electron attachment to the mixed acid-water complexes, namely $\mathrm{HNO}_{3} / \mathrm{H}_{2} \mathrm{O}^{156,157}$ and $\mathrm{H}_{2} \mathrm{SO}_{4} /$ $\mathrm{H}_{2} \mathrm{O} .{ }^{57}$ The former system was a representative example of the role of the environment in the DEA process, where the solvent molecules influence the reaction pathways and change the products. The DEA of an isolated $\mathrm{HNO}_{3}$ molecule yielded almost exclusively $\mathrm{NO}_{2}{ }^{-}$ions $(96.5 \%)$ and the minor product $\mathrm{OH}^{-}(3.4 \%)$. The nitrate anion $\mathrm{NO}_{3}{ }^{-}$had an abundance of less than $0.1 \%$. This picture changed completely in the mixed $\left(\mathrm{HNO}_{3}\right)_{M}\left(\mathrm{H}_{2} \mathrm{O}\right)_{N}$ clusters, where the negatively charged cluster ion fragments with $\mathrm{NO}_{3}{ }^{-}$dominated the mass spectra with $57 \%$ abundance. It was interpreted by the acidic dissociation of $\mathrm{HNO}_{3}$ molecules in the water containing clusters, and by cascade intracluster ion-molecule reactions terminated by $\mathrm{NO}_{3}{ }^{-}$. The cluster ions containing $\mathrm{HNO}_{3}{ }^{-}$were also detected in significant amounts (8\%). This ion was not formed in the gas phase DEA, and its generation in the clusters was attributed to the stabilization of $\mathrm{HNO}_{3}{ }^{-}$by caging. The measured energy dependence of the $\mathrm{DEA}^{157}$ revealed that the degree to which the major gas phase product $\mathrm{NO}_{2}{ }^{-}$is converted to $\mathrm{NO}_{3}{ }^{-}$in the clusters depends strongly on the electron energy: namely $\mathrm{NO}_{2}{ }^{-}$ prevails at low electron energies below approximately $3.5 \mathrm{eV}$, while $\mathrm{NO}_{3}{ }^{-}$is the major product at higher energies.

The atmospheric relevance of these experiments is underlined by the fact that $\mathrm{NO}_{2}{ }^{-}$and $\mathrm{NO}_{3}{ }^{-}$are among the most abundant anions in the atmosphere having a strong influence on the aerosol generation and other processes. ${ }^{245-247}$ In addition, the proposed negative ion reactions in $\left(\mathrm{HNO}_{3}\right)_{M}\left(\mathrm{H}_{2} \mathrm{O}\right)_{N}$ clusters yield the $\mathrm{OH}^{\bullet}$ radical and HONO as the neutral products, which can be evaporated from the particles to the atmosphere. They represent the key species in atmospheric chemistry, namely the hydroxyl radical is the major oxidation agent. ${ }^{45}$ The photolysis of nitrous acid serves as the source of $\mathrm{OH}^{\bullet}$ in urban areas; yet the detailed mechanism of its formation is still discussed.

The experiments in M. Beyer's group, in which the negatively charged water clusters $\left(\mathrm{H}_{2} \mathrm{O}\right)_{n}{ }^{-}$are generated and subsequently react with molecules, ${ }^{56,248-252}$ can represent a complementary approach to our investigations of the electron attachment in water clusters. The $\left(\mathrm{H}_{2} \mathrm{O}\right)_{n}{ }^{-}$clusters represent the solvated electron $e_{\mathrm{aq}}{ }^{-}$in the gas phase. ${ }^{56,252}$ This way, the reaction of $\mathrm{CF}_{2} \mathrm{Cl}_{2}$ with the solvated electron was investigated. ${ }^{250}$ The reaction yielded the $\left(\mathrm{H}_{2} \mathrm{O}\right)_{n} \mathrm{Cl}^{-}$product, and the reaction enthalpy was determined. These results demonstrated that $\mathrm{CF}_{2} \mathrm{Cl}_{2}$ can undergo the dissociative electron transfer in condensed aqueous environments if thermalized hydrated electrons are present. It can be relevant to the atmospheric chemistry of ozone depletion, since the earlier studies ${ }^{253,254}$ revealed huge enhancement of the bond cleavage in $\mathrm{CF}_{2} \mathrm{Cl}_{2}$ and other chloro-fluoro-carbon compounds due to the dissociative electron transfer on ice surfaces. Later on, this process was proposed as the mechanism enhancing the $\mathrm{Cl}^{\bullet}$ radical yield in PSCs $;{ }^{255}$ however, the actual contribution of this process to ozone depletion remains questionable. ${ }^{256-260}$ The study revealed the details and energetics of the dissociative electron transfer process at the molecular level, but its relevance for the stratospheric ozone depletion could not be established by laboratory experiments. ${ }^{250}$

Hydrogen peroxide, $\mathrm{H}_{2} \mathrm{O}_{2}$, plays an important role in many areas of atmospheric and interstellar chemistry as a source of $\mathrm{HO}_{x}$ radicals ${ }^{261,262}$ and oxidation agent contributing to the aerosol nucleation. ${ }^{45,46,151,153}$ We have investigated the electron attachment to hydrogen peroxide $\left(\mathrm{H}_{2} \mathrm{O}_{2}\right)$ adsorbed on $\mathrm{Ar}_{N}$ and ice $\left(\mathrm{H}_{2} \mathrm{O}\right)_{N}$ nanoparticles. ${ }^{66}$ The hydrogen peroxide coagulates to $\left(\mathrm{H}_{2} \mathrm{O}_{2}\right)_{M}$ clusters on $\mathrm{Ar}_{N}$, as illustrated by the mass spectra in Fig. 6. The electron attachment to the $\left(\mathrm{H}_{2} \mathrm{O}_{2}\right)_{M}$ clusters on $\mathrm{Ar}_{N}$ 


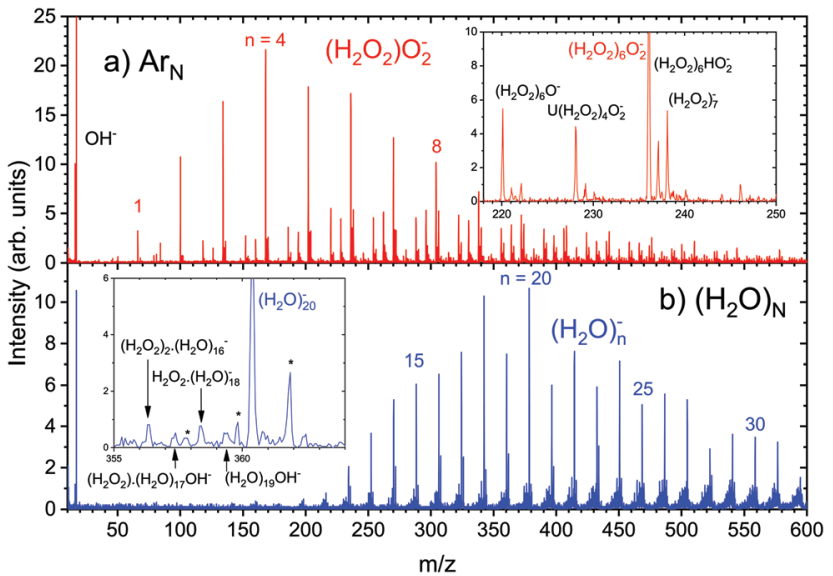

Fig. 7 Negative ion mass spectra of $\mathrm{H}_{2} \mathrm{O}_{2}$ molecules picked up on (a) $\mathrm{Ar}_{\mathrm{N}}$, $\bar{N} \approx 160$, and $(b)\left(\mathrm{H}_{2} \mathrm{O}\right)_{N}, \bar{N} \approx 120$. The spectra recorded at the electron energies between $\mathrm{O}$ and $5 \mathrm{eV}$ were integrated. The spectrum (a) is dominated by the $\left(\mathrm{H}_{2} \mathrm{O}_{2}\right)_{m} \mathrm{O}_{2}{ }^{-}$ion series as indicated, and further ion series are shown in the inset. All ions have been discussed in ref. 66 . The spectrum (b) is dominated by the water $\left(\mathrm{H}_{2} \mathrm{O}\right)_{n}{ }^{-}$series, and further minor ions containing $\mathrm{H}_{2} \mathrm{O}_{2}$ are shown in the inset (the star indicates metastable species).

yielded $\left(\mathrm{H}_{2} \mathrm{O}_{2}\right)_{m} \mathrm{O}_{2}{ }^{-}$ions as the major products, as shown in Fig. 7a. There are further weaker $\mathrm{O}_{2}{ }^{-}$containing series, and also $\mathrm{HO}_{2}{ }^{-}$and other ions (see the inset of Fig. 7a and ref. 66 for discussion). The presence of $\mathrm{O}_{2}{ }^{-}$ions was surprising, since they could not be generated in the DEA of the isolated $\mathrm{H}_{2} \mathrm{O}_{2}$ molecule. Nandi et al. ${ }^{263}$ showed that the DEA of $\mathrm{H}_{2} \mathrm{O}_{2}$ yielded only $\mathrm{OH}^{-}(75 \%)$ and $\mathrm{O}^{-}(25 \%)$. We have proposed possible reaction pathways leading from the nascent $\mathrm{OH}^{-}$and $\mathrm{O}^{-}$ions to the observed $\mathrm{O}_{2}{ }^{-}, \mathrm{HO}_{2}{ }^{-}$and the other ions in the spectra in ref. 66.

On the other hand, $\mathrm{O}_{2}{ }^{-}$is a well known product of the reaction of solvated electron with $\mathrm{H}_{2} \mathrm{O}_{2}$ in aqueous solutions in radiation chemistry. ${ }^{264-266}$ Therefore, we have investigated also $\mathrm{H}_{2} \mathrm{O}_{2}$ adsorbed on the $\left(\mathrm{H}_{2} \mathrm{O}\right)_{N}$ clusters, where the electron attachment yields the solvated electron $\left(\mathrm{H}_{2} \mathrm{O}\right)_{n}{ }^{-}$. The uptake of $\mathrm{H}_{2} \mathrm{O}_{2}$ molecules on $\left(\mathrm{H}_{2} \mathrm{O}\right)_{N}$ was proved by the positive spectrum in Fig. 6b. Nevertheless, the negative ion spectrum is dominated by $\left(\mathrm{H}_{2} \mathrm{O}\right)_{n}{ }^{-}$and no $\mathrm{O}_{2}{ }^{-}$containing products were detected, as shown in Fig. $7 \mathrm{~b}$. The $\left(\mathrm{H}_{2} \mathrm{O}\right)_{n}{ }^{-}$series was also observed in the electron attachment to the pure water clusters. ${ }^{267}$ There are other negative ion series of minor abundance, pointing to the presence of $\mathrm{H}_{2} \mathrm{O}_{2}$, illustrated in the inset of Fig. 7b. It is worth noting that a relatively strong $\mathrm{OH}^{-}$peak at $m / z=17$ is observed in both spectra in Fig. 6. The DEA of $\mathrm{H}_{2} \mathrm{O}_{2}$ yields $\mathrm{OH}^{-}$, which leaves the clusters. Although the analysis of the spectrum in Fig. $7 \mathrm{~b}$ might be still tentative, it is clear that none of the strong peaks could be assigned to $\mathrm{O}_{2}{ }^{-}$containing ions. Thus, the reaction of $e_{\mathrm{aq}}{ }^{-}$with $\mathrm{H}_{2} \mathrm{O}_{2}$ yielding $\mathrm{O}_{2}{ }^{-}$was not observed in the case of $\left(\mathrm{H}_{2} \mathrm{O}\right)_{N}$ clusters. The cluster environment changed the chemistry in a way, which could not be predicted based on the free DEA in the gas phase, nor based on the known chemistry of $\mathrm{H}_{2} \mathrm{O}_{2}$ in the bulk aqueous solutions and the reactions with the solvated electrons. It was even different from the chemistry of the electron attachment to the $\mathrm{H}_{2} \mathrm{O}_{2}$ clusters on $\mathrm{Ar}_{N}$.

\section{Conclusions, challenges and perspectives of the pickup experiments}

We have reviewed a few examples of the experiments with the pickup and reactions of molecules on clusters from the perspective of atmospheric and interstellar chemistry. The uptake cross sections of the ice nanoparticles for various molecules were determined. The cross section for the pickup of water molecules turned out to be substantially larger than the geometrical cross section, which is important for the nucleation of water aerosols.

The pickup experiments with the smaller hydrated nitric acid clusters enabled determination of purely kinetic surface accommodation coefficient for the proxies of ultrafine aerosol particles. We have established a promising method providing important parameters for atmospheric aerosol modeling; nevertheless, the method is not universal. When the character of the mass spectra with and without pickup is different, the pickup probability cannot be evaluated as the ratio of the integrated spectra. Such was the case for the uptake of molecules on hydrated sulfuric acid clusters. The investigation of sulfuric acid clusters is thus challenging, yet highly desirable, and will be followed in the future.

Some questions were touched in our pickup studies; yet future work can answer them more comprehensively. For example, the coagulation of molecules on nanoparticles could be modeled in more detail to understand their mobility and interplay of the bonds. Also the question of molecules submerging into the cluster or remaining on its surface should be addressed in more detail.

A clear perspective to follow in the future was shown by the experiments with the pickup of dimethylamine on the hydrated nitric acid clusters, which pointed to the acid-base reaction in the neutral clusters. From a purely fundamental point of view, it can provide molecular-level insight into the basic chemistry. In the atmosphere, such systems play the key role in the new particle formation.

This will be one of our major directions in future studies. On our way towards the clusters of atmospheric relevance, we have moved from rare gas model systems to water clusters, and recently to mixed binary systems such as nitric acid-water clusters. Evidence from aerosol field measurements and model simulations suggests that the new particle formation in the atmosphere is most likely dominated by ternary nucleation of $\mathrm{H}_{2} \mathrm{SO}_{4}-\mathrm{H}_{2} \mathrm{O}-\mathrm{NH}_{3}$ and subsequent condensation of semivolatile organic compounds (SVOCs). ${ }^{268}$ Clusters mimicking the composition of the real atmospheric aerosols should be generated. The present experiments with $\mathrm{HNO}_{3}-\mathrm{H}_{2} \mathrm{O}$ clusters and DMA pickup represent the first steps in this direction in our experiments. We will continue generating clusters of hydrated inorganic acids (nitric acid, sulfuric acid, methanesulfonic acid) with bases (ammonia, amines). The pickup of other 
atmospheric molecules, such as SVOCs, by these clusters will be studied, providing uptake coefficients for atmospheric modeling. Another challenging project represents incorporating a radical source into the pickup region of our CLUB apparatus and embedding radicals, such as $\mathrm{OH}^{\bullet}$, into the clusters. This will open the doorway to radical chemistry investigations in these clusters. The reactions of radicals, positive and negative ions and excited species in the clusters can contribute to the understanding of the atmospheric aerosol chemistry.

In relevance to the polar stratospheric clouds and ozone depletion we have reviewed the photodissociation of hydrogen halides and $\mathrm{CF}_{2} \mathrm{Cl}_{2}$ on the ice nanoparticles. In the case of $\mathrm{HX}$, our experiments revealed their acidic dissociation to the $\mathrm{H}_{3} \mathrm{O}^{+} \cdots \mathrm{X}^{-}$ion pair in the ground state, analogous to the above acid-base reaction of DMA. However, it is interesting to note that the acid-base reaction in the DMA case was revealed by mass spectrometry, while in the HX case a completely different photochemistry experiment in synergy with theory provided the evidence. Further extension of this work to the photodissociation of molecules on the mixed nitric acid-water clusters and to the clusters with sulfuric acid is planned also with other molecules involved in the ozone depletion, e.g., $\mathrm{ClONO}_{2}, \mathrm{CH}_{3} \mathrm{Cl}, \mathrm{Cl}_{2}$, $\mathrm{HOCl}$.

We have discussed reactions between molecules deposited on the nanoparticles triggered by electrons or photons. The first reactions observed between two different molecules on $\operatorname{Ar}_{N}$ were the proton transfer processes between methanol and formic acid. Here, a vast field is opened for simulating atmospheric and interstellar chemistry, e.g., reactions of different molecules on carbonaceous and PAH clusters, and ice nanoparticles including also other than water nanoices.

Finally, reactions triggered by slow electron attachment in molecules deposited on clusters were revealed. Generally, the reactions of negatively charged ions have been investigated less extensively compared to the positive ion chemistry, and thus the negatively charged clusters represent a large relatively unexplored field.

In terms of the experiment, the following challenges may be defined: (1) new ways of cluster generation with improved control of cluster composition and size; (2) implementing the action spectroscopy to provide information about the bonding motifs and structure of the fragments; (3) detect and analyze the neutral fragments in addition to the charged ones.

\section{Author contributions}

MF: conceptualization, methodology, writing-original draft, review and editing, visualization, supervision, funding acquisition, project administration; JF: methodology, writing-review and editing; JK: investigation, writing-review and editing; JL: investigation, writing-review and editing; EP: software, writing-review and editing; VP: investigation, writing-review and editing; AP: investigation, formal analysis, visualization.

\section{Conflicts of interest}

There are no conflicts of interest to declare.

\section{Acknowledgements}

The authors acknowledge the support of Praemium Academiae of the Czech Academy of Sciences.

\section{References}

1 A. W. Castleman and R. G. Keesee, Science, 1988, 241, 36-42.

2 A. W. Castleman, Int. J. Mass Spectrom. Ion Processes, 1992, 118-119, 167-189.

3 B. Brutschy, Chem. Rev., 1992, 92, 1567-1587.

4 A. W. Castleman and S. Wei, Annu. Rev. Phys. Chem., 1996, 45, 685-719.

5 T. D. Märk, Linking the gaseous and condensed phases of matter, Plenum Press, New York, 1994, p. 155.

6 A. W. Castleman and K. H. Bowen, J. Phys. Chem., 1996, 100, 12900-12944.

7 H. Haberland, Clusters of Atoms and Molecules, Springer, Berlin, 1994.

8 H. Pauly, Atom, Molecule and Cluster Beams II: Cluster Beams, Fast and Slow Beams, Accessory Equipment and Applications, Springer, Berlin, 2000, pp. 71-136.

9 T. S. Zwier, Annu. Rev. Phys. Chem., 1996, 47, 205-241.

10 C. Dedonder-Lardeux, G. Grégoire, C. Jouvet, S. Martrenchard and D. Solgadi, Chem. Rev., 2000, 100, 4023-4037.

11 P. Jena and A. W. Castleman, Proc. Natl. Acad. Sci. U. S. A., 2006, 103, 10560.

12 Y. D. Kim, Int. J. Mass Spectrom., 2004, 238, 17-31.

13 U. Heiz and U. Landman, Nanocatalysis, Springer-Verlag, Berlin Heidelberg, 2007.

14 P. Jena and A. W. Castleman, Nanoclusters: A Bridge Across Disciplines, Elsevier, Amsterdam, 2010.

15 M. Hartmann, R. E. Miller, J. P. Toennies and A. F. Vilesov, Phys. Rev. Lett., 1995, 75, 1566.

16 J. P. Toennies, A. F. Vilesov and K. B. Whaley, Phys. Today, 2001, 2, 31-37.

17 J. P. Toennies and A. F. Vilesov, Angew. Chem., Int. Ed., 2004, 43, 2622-2648.

18 M. Y. Choi, G. E. Douberly, T. M. Falconer, W. K. Lewis, C. M. Lindsay, J. M. Merritt, P. L. Stiles and R. E. Miller, Int. Rev. Phys. Chem., 2006, 25, 15.

19 F. Stienkemeier and K. K. Lehmann, J. Phys. B, 2006, 39, R127-R166.

20 M. Mudrich and F. Stienkemeier, Int. Rev. Phys. Chem., 2014, 33, 301-339.

21 A. Mauracher, O. Echt, A. M. Ellis, S. Yang, D. K. Bohme, J. Postler, A. Kaiser, S. Denifl and P. Scheier, Phys. Rep., 2018, 751, 1-90.

22 J. M. Mestdagh, M. A. Gaveau, C. Gée, O. Sublemontier and J. P. Visticot, Int. Rev. Phys. Chem., 1997, 16, 215.

23 A. Lallement, J. M. Mestdagh, P. Meynadier, P. de Pujo, O. Sublemontier, J.-P. Visticot, J. Berlande, X. Biquard, J. Cuvellier and C. G. Hickman, J. Chem. Phys., 1993, 99, 8705.

24 A. Lallement, O. Sublemontier, J.-P. Visticot, A. J. Bell, J. Berlande, J. C. J. M. Mestdagh and P. Meynadier, Chem. Phys. Lett., 1993, 204, 440-444. 
25 X. Biquard, O. Sublemontier, J. Berlande, M. A. Gaveau, J. M. Mestdagh, B. Schilling and J. P. Visticot, J. Chim. Phys., 1995, 92, 264-282.

26 X. Biquard, O. Sublemontier, J. Berlande, M. A. Gaveau, J. M. Mestdagh and J. P. Visticot, J. Chem. Phys., 1995, 103, 957.

27 C. Gée, M. A. Gaveau, J. M. Mestdagh, M. Osborne, O. Sublemontier and J.-P. Visticot, J. Phys. Chem., 1996, 100, 13421-13427.

28 C. Gée, M. A. Gaveau, O. Sublemontier, J. M. Mestdagh and J.-P. Visticot, J. Chem. Phys., 1997, 107, 4194.

29 M. A. Osborne, M. A. Gaveau, C. Gee, O. Sublemontier, J. M. Mestdagh and J.-P. Visticot, J. Chem. Phys., 1997, 106, 1449.

30 W. H. Breckenridge, P. R. Fournier, M. A. Gaveau, J. M. Mestdagh and J.-P. Visticot, Chem. Phys. Lett., 2002, 364, 225-230.

31 M. Briant, M. A. Gaveau, J. M. Mestdagh and J.-P. Visticot, J. Chem. Phys., 2000, 112, 1744.

32 M. Briant, P. R. Fournier, M. A. Gaveau, J. M. Mestdagh, B. Soep and J. P. Visticot, J. Chem. Phys., 2002, 117, 5036.

33 M.-A. Gaveau, E. Glogauen, P.-R. Fournier and J.-M. Mestdagh, J. Phys. Chem. A, 2005, 109, 9494.

34 S. Awali, L. Poisson, B. Soep, M.-A. Gaveau, M. Briant, C. Pothier, J.-M. Mestdagh, M. B. E. H. Rhouma, M. Hochlaf, V. Mazet and S. Faisan, Phys. Chem. Chem. Phys., 2014, 16, 516-526.

35 S. Awali, M.-A. Gaveau, M. Briant, J.-M. Mestdagh, B. Soep, O. Gobert, R. Maksimenka and L. Poisson, Phys. Chem. Chem. Phys., 2016, 18, 32378-32386.

36 U. Buck, J. Phys. Chem. A, 2002, 106, 10049.

37 M. Fárník, N. H. Nahler, U. Buck, P. Slavíček and P. Jungwirth, Chem. Phys., 2005, 315, 161.

38 M. Fárník and U. Buck, Int. Rev. Phys. Chem., 2006, 25, 583.

39 C. Vallance, Astrochemistry, World Scientific, Oxford, 2017.

40 E. Herbst and E. F. van Dishoeck, Annu. Rev. Astron. Astrophys., 2009, 47, 427-480.

41 T. Hama and N. Watanabe, Chem. Rev., 2013, 113, 8783-8839.

42 S. H. Lee, H. Gordon, H. Yu, K. Lehtipalo, R. Haley, Y. Li and R. Zhang, J. Geophys. Res.: Atmos., 2018, 124, 7098-7146.

43 M. Fárník and J. Lengyel, Mass Spectrom. Rev., 2018, 37, 630-651.

44 A. R. Ravishankara, Science, 1997, 276, 1058-1065.

45 B. J. Finlayson-Pitts and J. N. Pitts, Chemistry of the upper and lower atmosphere, Academic Press, San Diego, 2000.

46 J. H. Seinfeld and S. N. Pandis, Atmospheric Chemistry and Physics: From Air Pollution to Climate Change, John Wiley \& Sons Inc., Hoboken, NJ, 3rd edn, 2016.

47 E. M. Dunne, H. Gordon, A. Kürten, J. Almeida, J. Duplissy, C. Williamson, I. K. Ortega, K. J. Pringle, A. Adamov, U. Baltensperger, P. Barmet, F. Benduhn, F. Bianchi, M. Breitenlechner, A. Clarke, J. Curtius, J. Dommen, N. M. Donahue, S. Ehrhart, R. C. Flagan, A. Franchin, R. Guida, J. Hakala, A. Hansel, M. Heinritzi, T. Jokinen, J. Kangasluoma, J. Kirkby, M. Kulmala, A. Kupc, M. J. Lawler,
K. Lehtipalo, V. Makhmutov, G. Mann, S. Mathot, J. Merikanto, P. Miettinen, A. Nenes, A. Onnela, A. Rap, C. L. S. Reddington, F. Riccobono, N. A. D. Richards, M. P. Rissanen, L. Rondo, N. Sarnela, S. Schobesberger, K. Sengupta, M. Simon, M. Sipilä, J. N. Smith, Y. Stozkhov, A. Tomé, J. Tröstl, P. E. Wagner, D. Wimmer, P. M. Winkler, D. R. Worsnop and K. S. Carslaw, Science, 2016, 354, 1119-1124.

48 P. Nissenson, C. J. H. Knox, B. J. Finlayson-Pitts, L. F. Phillips and D. Dabdub, Phys. Chem. Chem. Phys., 2006, 8, 4700-4710.

49 B. J. Finlayson-Pitts, Phys. Chem. Chem. Phys., 2009, 11, 7760-7779.

50 V. Vaida, J. Chem. Phys., 2011, 135, 020901.

51 B. D. Kay, V. Hermann and A. W. Castleman, Chem. Phys. Lett., 1981, 80, 469-474.

52 X. Zhang, E. L. Mereand and A. W. Castleman, J. Phys. Chem., 1994, 98, 3554-3557.

53 R. S. MacTaylor and A. W. Castleman, J. Atmos. Chem., 2000, 36, 23-63.

54 J. J. Gilligan and A. W. Castleman, J. Phys. Chem. A, 2001, 105, 5601-5605.

55 G. Niedner-Schatteburg and V. E. Bondybey, Chem. Rev., 2001, 100, 4059-4086.

56 O. P. Balaj, C.-K. Siu, I. Balteanu, M. K. Beyer and V. E. Bondybey, Int, J. Mass Spectrom., 2004, 238, 65-74.

57 J. Lengyel, A. Pysanenko and M. Fárník, Atmos. Chem. Phys., 2017, 17, 14171-14180.

58 T. I. Yacovitch, T. Wende, L. Jiang, N. Heine, G. Meijer, D. M. Neumark and K. R. Asmis, J. Phys. Chem. Lett., 2011, 2, 2135-2140.

59 T. I. Yacovitch, N. Heine, C. Brieger, T. Wende, C. Hock, D. M. Neumark and K. R. Asmis, J. Chem. Phys., 2012, 136, 241102.

60 T. I. Yacovitch, N. Heine, C. Brieger, T. Wende, C. Hock, D. M. Neumark and K. R. Asmis, J. Phys. Chem. A, 2013, 117, 7081-7090.

61 N. Heine and K. S. Asmis, Int. Rev. Phys. Chem., 2015, 34, 1-34. 62 V. Poterya, J. Lengyel, A. Pysanenko, P. Svrčková and M. Fárník, J. Chem. Phys., 2014, 141, 074309.

63 V. Poterya, J. Kočišek, J. Lengyel, P. Svrčková, A. Pysanenko, D. Hollas, P. Slavíček and M. Fárník, J. Phys. Chem. A, 2014, 118, 4740-4749.

64 M. Fárník and V. Poterya, Front. Chem., 2014, $2,4$.

65 J. Kočišek, A. Pysanenko, M. Fárník and J. Fedor, J. Phys. Chem. Lett., 2016, 7, 3401-3405.

66 A. Pysanenko, E. Pluhařová, I. S. Vinklárek, J. Rakovský, V. Poterya, J. Kočišek and M. Fárník, Phys. Chem. Chem. Phys., 2020, 22, 15312-15320.

67 J. Fedor, V. Poterya, A. Pysanenko and M. Fárník, J. Chem. Phys., 2011, 135, 104305.

68 J. Lengyel, J. Kočišek, V. Poterya, A. Pysanenko, P. Svrčková, M. Fárník, D. Zaouris and J. Fedor, J. Chem. Phys., 2012, 137, 034304.

69 J. Lengyel, A. Pysanenko, V. Poterya, P. Slavíček, M. Fárník, J. Kočišek and J. Fedor, Phys. Rev. Lett., 2014, 112, 113401. 
70 J. Fedor, J. Kočišek, V. Poterya, O. Votava, A. Pysanenko, L. Lipciuc, T. N. Kitsopoulos and M. Fárník, J. Chem. Phys., 2011, 134, 154303.

71 K. Grygoryeva, J. Rakovský, O. Votava and M. Fárník, J. Chem. Phys., 2018, 149, 094303.

72 J. Lengyel, A. Pysanenko, J. Kočišek, V. Poterya, C. Pradzynski, T. Zeuch, P. Slavíček and M. Fárník, J. Phys. Chem. Lett., 2012, 3, 3096-3109.

73 J. Kočišek, J. Lengyel and M. Fárník, J. Chem. Phys., 2013, 138, 124306.

74 P. Rubovič, A. Pysanenko, J. Lengyel, D. Nachtigallová and M. Fárník, J. Phys. Chem. A, 2016, 120, 4720-4730.

75 A. Pysanenko, F. Gámez, M. Fárník, J. Chalabala and P. Slavíček, J. Phys. Chem. A, 2020, 124, 3038-3047.

76 J. Lengyel, A. Pysanenko, V. Poterya, J. Kočišek and M. Fárník, Chem. Phys. Lett., 2014, 612, 256-261.

77 D. Šmídová, J. Lengyel, A. Pysanenko, J. Med, P. Slavíček and M. Fárník, J. Phys. Chem. Lett., 2015, 6, 2865-2869.

78 J. Lengyel, J. Kočišek, M. Fárník and J. Fedor, J. Phys. Chem. C, 2016, 120, 7397-7402.

79 D. Šmídová, J. Lengyel, J. Kočišek, A. Pysanenko and M. Fárník, Int. J. Mass Spectrom., 2017, 421, 144-149.

80 P. Svrčková, A. Pysanenko, J. Lengyel, P. Rubovič, J. Kočišek, V. Poterya, P. Slavíček and M. Fárník, Phys. Chem. Chem. Phys., 2015, 17, 25734-25741.

81 K. Grygoryeva, J. Kubečka, A. Pysanenko, J. Lengyel, P. Slavíček and M. Fárník, J. Phys. Chem. A, 2016, 120, 4139-4146.

82 T. E. Gough, M. Mengel, P. A. Rowntree and G. Scoles, J. Chem. Phys., 1985, 83, 4958.

83 S. Grebenev, J. P. Toennies and A. F. Vilesov, Science, 1998, 279, 2083.

84 G. Scoles and K. K. Lehmann, Science, 2000, 287, 2429.

85 E. Lugovoj, J. P. Toennies and A. F. Vilesov, J. Chem. Phys., 2000, 112, 8217.

86 M. Fárník and J. P. Toennies, J. Chem. Phys., 2005, 122, 014307.

87 J. M. Merritt, S. Rudić and R. E. Miller, J. Chem. Phys., 2006, 124, 084301.

88 S. Denifl, F. Zappa, I. Mähr, F. Ferreira da Silva, A. Aleem, A. Mauracher, M. Probst, J. Urban, P. Mach, A. Bacher, O. Echt, T. D. Märk and P. Scheier, Angew. Chem., Int. Ed., 2009, 121, 9102-9105.

89 M. Gatchell, M. Goulart, L. Kranabetter, M. Kuhn, P. Martini, B. Rasul and P. Scheier, Phys. Chem. Chem. Phys., 2018, 20, 7739-7745.

90 A. Gutiérrez-Quintanilla, M. Briant, E. Mengesha, M.-A. Gaveau, J.-M. Mestdagh, B. Soep, C. Crépin and L. Poisson, Phys. Chem. Chem. Phys., 2018, 20, 28658-28666.

91 L. Tiefenthaler, J. Ameixa, P. Martini, S. Albertini, L. Ballauf, M. Zankl, M. Goulart, F. Laimer, K. von Haeften, F. Zappa and P. Scheier, Rev. Sci. Instrum., 2020, 91, 033315.

92 L. F. Gomez, K. R. Ferguson, J. P. Cryan, C. Bacellar, R. M. P. Tanyag, C. Jones, S. Schorb, D. Anielski, A. Belkacem, C. Bernando, R. Boll, J. Bozek, S. Carron, G. Chen, T. Delmas, L. Englert, S. W. Epp, B. Erk,
L. Foucar, R. Hartmann, A. Hexemer, M. Huth, J. Kwok, S. R. Leone, J. H. S. Ma, F. R. N. C. Maia, E. Malmerberg, S. Marchesini, D. M. Neumark, B. Poon, J. Prell, D. Rolles, B. Rudek, A. Rudenko, M. Seifrid, K. R. Siefermann, F. P. Sturm, M. Swiggers, J. Ullrich, F. Weise, P. Zwart, C. Bostedt, O. Gessner and A. F. Vilesov, Science, 2014, 345, 906-909.

93 O. Gessner and A. F. Vilesov, Annu. Rev. Phys. Chem., 2019, 70, 173-198.

94 F. Huisken and M. Stemmler, J. Chem. Phys., 1993, 98, 7680 .

95 M. Ahmed, C. J. Apps, C. Hughes, N. E. Watt and J. C. Whitehead, J. Phys. Chem. A, 1997, 101, 1250.

96 M. Ahmed, C. J. Apps, R. Buesnel, C. Hughes, H. Hillier, N. E. Watt and J. C. Whitehead, J. Phys. Chem. A, 1997, 101, 1250.

97 R. Moro, R. Rabinovitch and V. V. Kresin, Rev. Sci. Instrum., 2005, 76, 056104.

98 R. Moro, R. Rabinovitch and V. V. Kresin, J. Chem. Phys., 2005, 123, 074301.

99 C. P. Schulz, R. Haugstätter, H. U. Tittes and I. V. Hertel, Phys. Rev. Lett., 1986, 57, 1703-1706.

100 C. Nitsch, C. P. Schulz, A. Gerber, W. Zimmermann-Edling and I. V. Hertel, Z. Phys. D, 1992, 22, 651.

101 C. Bobbert, S. Schütte, C. Steinbach and U. Buck, Eur. Phys. J. D, 2002, 19, 183-192.

102 U. Buck, C. C. Pradzinski, T. Zeuch, J. M. Dieterich and B. Hartke, Phys. Chem. Chem. Phys., 2014, 16, 6859-6871.

103 B. L. Yoder, J. H. Litman, P. W. Forysinski, J. L. Corbett and R. Signorell, J. Phys. Chem. Lett., 2011, 2, 2623-2628.

104 P. Forysinski, P. Zielke, D. Luckhaus, J. Corbett and R. Signorell, J. Chem. Phys., 2011, 134, 094314.

105 M. Huttula, M.-H. Mikkelä, M. Tchaplyguine and O. Björneholm, J. Electron Spectrosc. Relat. Phenom., 2010, 181, 145-149.

106 C. Zhang, T. Andersson, S. Svensson, O. Björneholm, M. Huttula, M.-H. Mikkelä, M. Tchaplyguine and G. Öhrwall, J. Chem. Phys., 2011, 134, 124507.

107 C. Zhang, T. Andersson, S. Svensson, O. Björneholm, M. Huttula, M.-H. Mikkelä, D. Anin, M. Tchaplyguine and G. Öhrwall, J. Phys. Chem. A, 2012, 116, 12104-12111.

108 L. Hautala, K. Jänkälä, M.-H. Mikkelä, M. Tchaplyguine and M. Huttula, Phys. Chem. Chem. Phys., 2015, 17, 7012-7022.

109 L. Hautala, K. Jänkälä, T. Löytynoja, M.-H. Mikkelä, N. L. Prisle, M. Tchaplyguine and M. Huttula, Phys. Rev. $B$, 2017, 95, 045402.

110 L. Partanen, M.-H. Mikkelä, M. Huttula, M. Tchaplyguine, C. Zhang, T. Andersson and O. Björneholm, J. Chem. Phys., 2013, 138, 044301.

111 L. Hautala, K. Jänkälä, M.-H. Mikkelä, P. Turunen, N. L. Prisle, M. Patanen, M. Tchaplyguine and M. Huttula, Phys. Chem. Chem. Phys., 2017, 19, 25158-25167.

112 J. Cuvellier, P. Meynadier, P. de Pujo, O. Sublemontier, J.P. Visticot, J. Berlande, A. Lallement and J.-M. Mestdagh, $Z$. Phys. D, 1991, 21, 265. 
113 J. H. Litman, B. L. Yoder, B. Schläppi and R. Signorell, Phys. Chem. Chem. Phys., 2013, 15, 940-949.

114 M. Ahmed and O. Kostko, Phys. Chem. Chem. Phys., 2020, 22, 2713-2737.

115 J. Farges, M. F. de Feraudy, B. Raoult and G. Torchet, Surf. Sci., 1981, 106, 95.

116 J. Farges, M. F. de Feraudy, B. Raoult and G. Torchet, J. Chem. Phys., 1983, 78, 5067.

117 G. Torchet, P. Schwartz, J. Farges, M. F. de Feraudy and B. Raoult, J. Chem. Phys., 1983, 79, 6196.

118 J. Farges, M. F. de Feraudy, B. Raoult and G. Torchet, J. Chem. Phys., 1986, 84, 3491.

119 G. Torchet, M. F. de Feraudy and B. Raoult, J. Chem. Phys., 1995, 103, 3074-3083.

120 U. Buck and R. Krohne, J. Chem. Phys., 1996, 105, 5408-5415.

121 A. D. Martino, M. Benslimane, M. Châtelet, C. Crozes, F. Padère and H. Vach, Z. Phys. D, 1993, 27, 185.

122 U. Buck and H. Meyer, Phys. Rev. Lett., 1984, 52, 109.

123 U. Buck and H. Meyer, J. Chem. Phys., 1986, 84, 4854.

124 U. Buck, J. Phys. Chem., 1988, 92, 1023.

125 R. Moro, R. Rabinovitch, C. Xia and V. V. Kresin, Phys. Rev. Lett., 2006, 97, 123401.

126 H. Bieker, J. Onvlee, M. Johny, L. He, T. Kierspel, S. Trippel, D. A. Horke and J. Küpper, J. Phys. Chem. A, 2019, 123, 7486-7490.

127 B. S. Kamerin, J. W. Niman and V. V. Kresin, J. Chem. Phys., 2020, 153, 081101.

128 J. Lengyel, A. Pysanenko, P. Rubovič and M. Fárník, Eur. Phys. J. D, 2015, 69, 269.

129 M. Macler and Y. K. Bae, J. Phys. Chem. A, 1997, 101, 145.

130 J. Vigué, P. Labastie and F. Calvo, Eur. Phys. J. D, 2000, 8, 265.

131 O. F. Hagena, Surf. Sci., 1981, 106, 101-116.

132 O. F. Hagena, Z. Phys. D, 1987, 4, 291-299.

133 O. F. Hagena, Rev. Sci. Instrum., 1992, 63, 2374-2379.

134 C. Huang, V. V. Kresin, A. Pysanenko and M. Fárník, J. Chem. Phys., 2016, 145, 104304.

135 V. Buch, S. Bauerecker, J. P. Devlin, U. Buck and J. K. Kazimirski, Int. Rev. Phys. Chem., 2004, 23, 375.

136 C. Li, M. Lippe, J. Krohn and R. Signorell, J. Chem. Phys., 2019, 151, 094305.

137 S. Zamith, P. Feiden, P. Labastie and J.-M. L'Hermite, Phys. Rev. Lett., 2010, 104, 103401.

138 S. Zamith, P. Feiden, P. Labastie and J.-M. L'Hermite, J. Chem. Phys., 2010, 133, 154305.

139 S. Zamith, G. de Tournadre, P. Labastie and J.-M. L'Hermite, J. Chem. Phys., 2013, 138, 034301.

140 S. Zamith, P. Feiden, P. Labastie and J.-M. L'Hermite, J. Chem. Phys., 2014, 141, 139901.

141 H. Vehkamäki, Classical Nucleation Theory in Multicomponent Systems, Springer-Verlag, Berlin, 2006.

142 R. Zhang, A. Khalizov, L. Wang, M. Hu and W. Xu, Chem. Rev., 2012, 112, 1957-2011.

143 B. E. Wyslouzil and J. Wölk, J. Chem. Phys., 2016, 145, 211702.
144 J. Wölk, R. Strey, C. H. Heath and B. E. Wyslouzil, J. Chem. Phys., 2002, 117, 4954.

145 A. Manka, D. Brus, A.-P. Hyvärinen, H. Lihavainen, J. Wölk and R. Strey, J. Chem. Phys., 2010, 132, 244505.

146 A. Manka, H. Pathak, S. Tanimura, J. Wölk, R. Strey and B. E. Wyslouzil, Phys. Chem. Chem. Phys., 2012, 14, 4505.

147 J. Wölk and R. Strey, J. Phys. Chem. B, 2001, 105, 11683-11701.

148 V. I. Kalikmanov, J. Chem. Phys., 2006, 124, 124505.

149 M. Kulmala, Atmos. Res., 2010, 98, 201.

150 H. Vehkamäki, M. J. McGrath, T. Kurtén, J. Julin, K. E. J. Lehtinen and M. Kulmala, J. Chem. Phys., 2012, 136, 094107.

151 R. J. Weber, J. J. Marti, P. H. McMurry, F. L. Eisele, D. J. Tanner and A. Jefferson, J. Geophys. Res., 1997, 102, 4375-4385.

152 R. J. Weber, P. H. McMurry, R. L. Mauldin, D. J. Tanner, F. L. Eisele, A. D. Clarke and V. N. Kapustin, Geophys. Res. Lett., 1999, 26, 307-310.

153 S.-L. Sihto, M. Kulmala, V.-M. K. M. D. Maso, T. Petäjä, I. Riipinen, H. Korhonen, F. A. R. Janson, M. Boy, A. Laaksonen and K. E. J. Lehtinen, Atmos. Chem. Phys., 2006, 6, 4079-4091.

154 M. Kulmala, I. Riipinen, M. Sipila, H. E. Manninen, T. Petaja, H. Junninen, M. D. Maso, G. Mordas, A. Mirme, M. Vana, A. Hirsikko, L. Laakso, R. M. Harrison, I. Hanson, C. Leung, K. E. J. Lehtinen and V.-M. Kerminen, Science, 2007, 318, 89-92.

155 T. Peter, Annu. Rev. Phys. Chem., 1997, 48, 785-822.

156 J. Lengyel, M. Ončák, J. Fedor, J. Kočišek, A. Pysanenko, M. K. Beyer and M. Fárník, Phys. Chem. Chem. Phys., 2017, 19, 11753-11758.

157 J. Lengyel, J. Fedor and M. Fárník, Phys. Chem. Chem. Phys., 2019, 21, 8691-8697.

158 A. Pysanenko, J. Lengyel and M. Fárník, J. Chem. Phys., 2017, 148, 154301.

159 J. Lengyel, A. Pysanenko, K. Fárníková, E. Pluhařová and M. Fárník, J. Phys. Chem. Lett., 2020, 11, 2101-2105.

160 B. J. Finlayson-Pitts and J. N. Pitts, Chemistry of the upper and lower atmosphere, Academic Press, San Diego, 2000, p. 969.

161 T. Huthwelker, M. Ammann and T. Peter, Chem. Rev., 2006, 106, 1375-1444.

162 P. Davidovits, C. E. Kolb, L. R. Williams, J. T. Jayne and D. R. Worsnop, Chem. Rev., 2006, 106, 1323-1354.

163 C. E. Kolb, R. A. Cox, J. P. D. Abbatt, M. Ammann, E. J. Davis, D. J. Donaldson, B. C. Garrett, C. George, P. T. Griffiths, D. R. Hanson, M. Kulmala, G. McFiggans, U. Poschl, I. Riipinen, M. J. Rossi, Y. Rudich, P. E. Wagner, P. M. Winkler, D. R. Worsnop and C. D. O'Dowd, Atmos. Chem. Phys., 2010, 10, 10561-10605.

164 R. Y. Zhang, I. Suh, J. Zhao, D. Zhang, E. C. Fortner, X. X. Tie, L. T. Molina and M. J. Molina, Science, 2004, 304, 1487-1490.

165 A. Laaksonen, M. Kulmala, C. D. O’Dowd, J. Joutsensaari, P. Vaattovaara, S. Mikkonen, K. E. J. Lehtinen, L. Sogacheva, M. Dal Maso, P. Aalto, T. Petäjä, A. Sogachev, Y. J. Yoon, H. Lihavainen, D. Nilsson, M. C. Facchini, F. Cavalli, S. Fuzzi, 
T. Hoffmann, F. Arnold, M. Hanke, K. Sellegri, B. Umann, W. Junkermann, H. Coe, J. D. Allan, M. R. Alfarra, D. R. Worsnop, M. L. Riekkola, T. Hyötyläinen and Y. Viisanen, Atmos. Chem. Phys., 2008, 8, 2657-2665.

166 J. N. Smith, M. J. Dunn, T. M. VanReken, K. Iida, M. R. Stolzenburg, P. H. McMurry and L. G. Huey, Geophys. Res. Lett., 2008, 35, L04808.

167 I. Riipinen, T. Yli-Juuti, J. R. Pierce, T. Petäjä, D. R. Worsnop, M. Kulmala and N. M. Donahue, Nat. Geosci., 2012, 5, 453-458.

168 N. M. Donahue, I. K. Ortega, W. Chuang, I. Riipinen, F. Riccobono, S. Schobesberger, J. Dommen, U. Baltensperger, M. Kulmala, D. R. Worsnop and H. Vehkamäki, Faraday Discuss., 2013, 165, 91-104.

169 J. Kirkby, J. Curtius, J. Almeida, E. Dunne, J. Duplissy, S. Ehrhart, A. Franchin, S. Gagne, L. Ickes, A. Kürten, A. Kupc, A. Metzger, F. Riccobono, L. Rondo, S. Schobesberger, G. Tsagkogeorgas, D. Wimmer, A. Amorim, F. Bianchi, M. Breitenlechner, A. David, J. Dommen, A. Downard, M. Ehn, R. C. Flagan, S. Haider, A. Hansel, D. Hauser, W. Jud, H. Junninen, F. Kreissl, A. Kvashin, A. Laaksonen, K. Lehtipalo, J. Lima, E. R. Lovejoy, V. Makhmutov, S. Mathot, J. Mikkilä, P. Minginette, S. Mogo, T. Nieminen, A. Onnela, P. Pereira, T. Petäajä, R. Schnitzhofer, J. H. Seinfeld, M. Sipilä, Y. Stozhkov, F. Stratmann, A. Tomé, J. Vanhanen, Y. Viisanen, A. Vrtala, P. E. Wagner, H. Walther, E. Weingartner, H. Wex, P. M. Winkler, K. S. Carslaw, D. R. Worsnop, U. Baltensperger and M. Kulmala, Nature, 2011, 476, 429-433.

170 S. Chee, N. Myllys, K. C. Barsanti, B. M. Wong and J. N. Smith, J. Phys. Chem. A, 2019, 123, 5640-5648.

171 S. Schobesberger, A. Franchin, F. Bianchi, L. Rondo,

J. Duplissy, A. Kürten, I. K. Ortega, A. Metzger, R. Schnitzhofer, J. Almeida, A. Amorim, J. Dommen, E. M. Dunne, M. Ehn, S. Gagné, L. Ickes, H. Junninen, A. Hansel, V.-M. Kerminen, J. Kirkby, A. Kupc, A. Laaksonen, K. Lehtipalo, S. Mathot, A. Onnela, T. Petäjä, F. Riccobono, F. D. Santos, M. Sipilä, A. Tomé, G. Tsagkogeorgas, Y. Viisanen, P. E. Wagner, D. Wimmer, J. Curtius, N. M. Donahue, U. Baltensperger, M. Kulmala and D. R. Worsnop, Atmos. Chem. Phys., 2015, 15, 55-78.

172 J. Almeida, S. Schobesberger, A. Kürten, I. K. Ortega, O. Kupiainen-Määttä, A. P. Praplan, A. Adamov, A. Amorim, F. Bianchi, M. Breitenlechner, A. David, J. Dommen, N. M. Donahue, A. Downard, E. Dunne, J. Duplissy, S. Ehrhart, R. C. Flagan, A. Franchin, R. Guida, J. Hakala, A. Hansel, M. Heinritzi, H. Henschel, T. Jokinen, H. Junninen, M. Kajos, J. Kangasluoma, H. Keskinen, A. Kupc, T. Kurtén, A. N. Kvashin, A. Laaksonen, K. Lehtipalo, M. Leiminger, J. Leppä, V. Loukonen, V. Makhmutov, S. Mathot, M. J. McGrath, T. Nieminen, T. Olenius, A. Onnela, T. Petäjä, F. Riccobono, I. Riipinen, M. Rissanen, L. Rondo, T. Ruuskanen, F. D. Santos, N. Sarnela, S. Schallhart, R. Schnitzhofer, J. H. Seinfeld, M. Simon, M. Sipilä, Y. Stozhkov, F. Stratmann, A. Tomé,
J. Tröstl, G. Tsagkogeorgas, P. Vaattovaara, Y. Viisanen, A. Virtanen, A. Vrtala, P. E. Wagner, E. Weingartner, H. Wex, C. Williamson, D. Wimmer, P. Ye, T. Yli-Juuti, K. S. Carslaw, M. Kulmala, J. Curtius, U. Baltensperger, D. R. Worsnop, H. Vehkamäki and J. Kirkby, Nature, 2013, 502, 359-363.

173 B. A. McGuire, Astrophys. J., Suppl. Ser., 2018, 239(17), 1-48.

174 P. D. Holtom, C. E. Bennett, Y. Osamura, N. J. Mason and R. I. Kaiser, Astrophys. J., 2005, 626, 940-952.

175 E. F. van Dishoeck, E. Herbst and D. A. Neufeld, Chem. Rev., 2013, 113, 9043-9085.

176 S. Pilling, E. Seperuelo Duarte, E. F. da Silveira, E. Balanzat, H. Rothard, A. Domaracka and P. Boduch, Astron. Astrophys., 2010, 509, A87.

177 F. Borget, F. Duvernay, G. Danger, P. Theulé, J.-B. Bossa, V. Vinogradoff, F. Mispelaer, S. Müller, D. Grote and T. Chiavassa, J. Phys. Org. Chem., 2015, 28, 163-169.

178 M. J. Abplanalp and R. I. Kaiser, Phys. Chem. Chem. Phys., 2019, 21, 16949-16980.

179 M. P. Bernstein, S. A. Sandford, L. J. Allamandola, J. S. Gillette, S. J. Clemett and R. N. Zare, Science, 1999, 283, 1135-1138.

180 E. Rauls and L. Hornekær, Astrophys. J., 2008, 679, 531-536.

181 A. Candian, J. Zhen and A. G. G. M. Tielens, Phys. Today, 2018, 71, 38-43.

182 A. K. Lemmens, S. Gruet, A. L. Steber, J. Antony, S. Grimme, M. Schnell and A. Rijs, Phys. Chem. Chem. Phys., 2019, 21, 3414-3422.

183 C. Joblin, L. Dontot, G. A. Garcia, F. Spiegelman, M. Rapacioli, L. Nahon, P. Parneix, T. Pino and P. Bréchignac, J. Phys. Chem. Lett., 2017, 8, 3697-3702.

184 S. Zamith, M.-C. Ji, J.-M. L'Hermite, C. Joblin, L. Dontot, M. Rapacioli and F. Spiegelman, J. Chem. Phys., 2019, 151, 194303.

185 H. A. B. Johansson, H. Zettergren, A. I. S. Holm, F. Seitz, H. T. Schmidt, P. Rousseau, A. aawicki, M. Capron, A. Domaracka, E. Lattouf, S. Maclot, R. Maisonny, B. Manil, J.-Y. Chesnel, L. Adoui, B. A. Huber and H. Cederquist, Phys. Rev. A: At., Mol., Opt. Phys., 2011, 84, 043201.

186 R. Delaunay, M. Gatchell, P. Rousseau, A. Domaracka, S. Maclot, Y. Wang, M. H. Stockett, T. Chen, L. Adoui, M. Alcamí, F. Martín, H. Zettergren, H. Cederquist and B. A. Huber, J. Phys. Chem. Lett., 2015, 6, 1536-1542.

187 M. Gatchell, M. H. Stockett, N. de Ruette, L. G. T. Chen, R. F. Nascimento, M. Wolf, E. K. Anderson, R. Delaunay, V. Vizcaino, P. Rousseau, L. Adoui, B. A. Huber, H. T. Schmidt, H. Zettergren and H. Cederquist, Phys. Rev. A: At., Mol., Opt. Phys., 2015, 92, 050702.

188 M. Mitsui, N. Ando and A. Nakajima, J. Phys. Chem. A, 2007, 111, 9644-9648.

189 N. Ando, M. Mitsui and A. Nakajima, J. Chem. Phys., 2008, 128, 154318.

190 M. Goulart, M. Kuhn, B. Rasul, J. Postler, M. Gatchell, H. Zettergren, P. Scheier and O. Echt, Phys. Chem. Chem. Phys., 2017, 19, 27968-27973. 
191 M. Miyazaki, A. Fujii, T. Ebata and N. Mikami, J. Phys. Chem. A, 2004, 108, 10656-10660.

192 Y. M. Ibrahim, M. Meot-Ner, E. H. Alshraeh, M. S. El-Shall and S. Scheiner, J. Am. Chem. Soc., 2005, 127, 7053-7064.

193 I. K. Attaha, S. P. Platt, M. Meot-Ner, M. S. El-Shall, S. G. Aziz and A. O. Alyoubi, Chem. Phys. Lett., 2014, 613, 45-53.

194 K. Chatterjee and O. Dopfer, Phys. Chem. Chem. Phys., 2017, 19, 32262-32271.

195 B. Xu, T. Stein, U. Ablikim, L. Jiang, J. Hendrix, M. HeadGordon and M. Ahmed, Faraday Discuss., 2019, 217, 414-433.

196 J. Bouwman, S. Horst and J. Oomens, ChemPhysChem, 2018, 19, 3211-3218.

197 M. A. R. George, M. Förstel and O. Dopfer, Angew. Chem., Int. Ed., 2020, 59, 12098-12104.

198 X. Biquard, O. Sublemontier, J. P. Visticot, J. M. Mestdagh, P. Meynadier, M. A. Gaveau and J. Berlande, Z. Phys. D, 1994, 30, 45-52.

199 M. Lewerenz, B. Schilling and J. P. Toennies, J. Chem. Phys., 1995, 102, 8191.

200 A. Pysanenko, A. Habartová, P. Svrčková, J. Lengyel, V. Poterya, M. Roeselová, J. Fedor and M. Fárník, J. Phys. Chem. A, 2015, 119, 8991-8999.

201 M. P. Bernstein, J. P. Dworkin, S. A. Sandford, G. W. Cooper and L. J. Allamandola, Nature, 2002, 416, 401-403.

202 G. M. M. Caro, U. J. Meierhenrich, W. A. Schutte, B. Barbier, A. A. Segovia, H. Rosenbauer, W. H.-P. Thiemann, A. Brack and J. M. Greenberg, Nature, 2002, 416, 403-406.

203 N. Goldman and I. Tamblyn, J. Phys. Chem. A, 2013, 117, 5124-5131.

204 A. Pysanenko, J. Kočišek, V. Poterya and M. Fárník, J. Phys. Chem. A, 2017, 121, 1069-1077.

205 K. Grygoryeva, M. Ončák, A. Pysanenko and M. Fárník, Phys. Chem. Chem. Phys., 2019, 21, 8221-8227.

206 F. Gámez, A. Pysanenko, M. Fárník and M. Ončák, Phys. Chem. Chem. Phys., 2019, 21, 19201-19208.

207 V. Poterya, M. Fárník, P. Slavíček, U. Buck and V. V. Kresin, J. Chem. Phys., 2007, 126, 071101.

208 M. Fárník, A. Pysanenko, K. Moriová, L. Ballauf, P. Scheier, J. Chalabala and P. Slavíček, J. Phys. Chem. A, 2018, 122, 8458-8468.

209 A. Pysanenko, F. Gámez, K. Fárníková, E. Pluhařová and M. Fárník, J. Phys. Chem. A, 2019, 123, 7201-7209.

210 R. Schinke, Photodissociation dynamics, Cambridge University Press, Cambridge, 1993, pp. 8-10.

211 H. Sato, Annu. Rep. Prog. Chem., Sect. C: Phys. Chem., 2004, 100, 73-98.

212 A. L. Harris, J. K. Brown and C. B. Harris, Ann. Rev. Phys. Chem., 1988, 39, 341.

213 R. B. Gerber, A. B. McCoy and A. García-Vela, Ann. Rev. Phys. Chem., 1994, 45, 275-314.

214 R. Alimi and R. B. Gerber, Phys. Rev. Lett., 1990, 64, 1453. 215 S. Solomon, R. R. Garcia, F. S. Rowland and D. J. Wuebbles, Nature, 1986, 321, 755.
216 S. Solomon, Rev. Geophys., 1999, 37, 275-316.

217 K. Kawamura, Y. Imai and L. A. Barrie, Atmos. Environ., 2005, 39, 599-614.

218 R. Bianco and J. Hynes, Acc. Chem. Res., 2006, 39, 159.

219 A. L. Sobolewski and W. Domcke, Phys. Chem. Chem. Phys., 2002, 4, 4.

220 A. L. Sobolewski and W. Domcke, J. Phys. Chem. A, 2003, $107,1557$.

221 A. L. Sobolewski and W. Domcke, J. Chem. Phys., 2005, $122,184320$.

222 A. L. Sobolewski and W. Domcke, Phys. Chem. Chem. Phys., 2007, 9, 3818.

223 F. Uhlig, O. Marsalek and P. Jungwirth, Phys. Chem. Chem. Phys., 2011, 13, 14003-14009.

224 M. Ončák, P. Slavíček, V. Poterya, M. Fárník and U. Buck, J. Phys. Chem. A, 2008, 112, 5344-5353.

225 V. Poterya, J. Fedor, A. Pysanenko, O. Tkáč, J. Lengyel, M. Ončák, P. Slavíček and M. Fárník, Phys. Chem. Chem. Phys., 2011, 13, 2250-2258.

226 M. Ončák, P. Slavíček, M. Fárník and U. Buck, J. Phys. Chem. A, 2011, 115, 6155-6168.

227 V. Poterya, J. Kočišek, A. Pysanenko and M. Fárník, Phys. Chem. Chem. Phys., 2014, 16, 421-429.

228 B. Brutschy, J. Phys. Chem., 1990, 94, 8637-8647.

229 C. G. Nolte, P. A. Solomon, T. Fall, L. G. Salmon and G. R. Cass, Environ. Sci. Technol., 1997, 31, 2547-2553.

230 A. J. Eugene and M. I. Guzmán, J. Phys. Chem. A, 2017, 121, 2924-2935.

231 A. E. Reed Harris, A. Pajunoja, M. Cazaunau, A. Gratien, E. Pangui, A. Monod, E. C. Griffith, A. Virtanen, J. F. Doussin and V. Vaida, J. Phys. Chem. A, 2017, 121, 3327-3339.

232 W. A. Brown and A. S. Bolina, Mon. Not. R. Astron. Soc., 2007, 374, 1006-1014.

233 P. Ehrenfreund, L. d'Hendecourt, E. Dartois, M. Jourdain de Muizon, M. Breitfellner, J. L. Puget and H. J. Habing, Icarus, 1997, 130, 1-15.

234 E. L. Gibb, D. C. B. Whittet, A. C. A. Boogert and A. G. G. M. Tielens, Astrophys. J., Suppl. Ser., 2004, 151, 35-73.

235 K. M. Pontoppidan, E. F. van Dishoeck and E. Dartois, Astron. Astrophys., 2004, 426, 925-940.

236 N. Biver, D. Bockelée-Morvan, P. Colom, J. Crovisier, J. K. Davies, W. R. F. Dent, D. Despois, E. Gérard, E. Lellouch, H. Rauer, R. Moreno and G. Paubert, Science, 1997, 275, 1915-1918.

237 K. I. Öberg, R. T. Garrot, E. F. van Dishoeck and H. Linnartz, Astron. Astrophys., 2009, 504, 891-913.

238 K.-J. Chuang, G. Fedoseev, S. Ippolo, E. F. van Dishoeck and H. Linnartz, Mon. Not. R. Astron. Soc., 2016, 455, 1702-1712.

239 J. Cernicharo, N. Marcelino, E. Roueff, M. Gerin, A. Jiménez-Escobar and G. M. M. Noz Caro, Astrophys. J., 2012, 759, L43.

240 C. Bermudez, S. Bailleux and J. Cernicharo, Astron. Astrophys., 2017, 598, A9.

241 I. I. Fabrikant, S. Eden, N. J. Mason and J. Fedor, Advances In Atomic, Molecular, and Optical Physics, Elsevier Inc., Academic Press, 2017, vol. 66, pp. 545-657. 
242 T. D. Märk, Int. J. Mass Spectrom. Ion Processes, 1991, 107, 143-163.

243 O. Ingólfsson, F. Weik and E. Illenberger, Int. J. Mass Spectrom., 1996, 155, 1-68.

244 I. I. Fabrikant, Eur. Phys. J. D, 2018, 72, 96.

245 A. A. Viggiano and F. Arnold, Planet. Space Sci., 1981, 29, 895-906.

246 D. Smith and P. Španěl, Mass Spectrom. Rev., 1995, 14, 255-278.

247 F. Arnold, Space Sci. Rev., 2008, 137, 225-239.

248 O. P. Balaj, C.-K. Siu, I. Balteanu, M. K. Beyer and V. E. Bondybey, Chem. - Eur. J., 2004, 10, 4822-4830.

249 S. J. Retmeier, O. P. Balaj, V. E. Bondybey and M. K. Beyer, Int. J. Mass Spectrom., 2006, 249, 106-111.

250 J. Lengyel, C. van der Linde, M. Fárník and M. K. Beyer, Phys. Chem. Chem. Phys., 2016, 18, 23910-23915.

251 C. van der Linde, W. K. Tang, C.-K. Siu and M. K. Beyer, Phys. Chem. Chem. Phys., 2018, 20, 10838-10845.

252 A. Herburger, E. Barwa, M. Ončák, J. Heller, C. van der Linde, D. M. Neumark and M. K. Beyer, J. Am. Chem. Soc., 2019, 141, 18000-18003.

253 Q.-B. Lu and T. E. Madey, J. Chem. Phys., 1999, 111, 2861. 254 Q.-B. Lu and L. Sanche, Phys. Rev. Lett., 2001, 87, 078501. 255 Q.-B. Lu, Phys. Rep., 2010, 487, 141-167.
256 R. Müller, Phys. Rev. Lett., 2003, 91, 058502.

257 J.-U. Grooß and R. Müller, Atmos. Environ., 2011, 45, 3508-3514.

258 J.-U. Grooß and R. Müller, Atmos. Environ., 2013, 68, 350.

259 R. Müller and J.-U. Grooß, Int. J. Mod. Phys. B, 2014, 28, 1482001.

260 Q.-B. Lu, Int. J. Mod. Phys. B, 2014, 28, 1475003.

261 S. Versick, G. P. Stiller, T. von Clarmann, T. Reddmann, N. Glatthor, U. Grabowski, M. Höpfner, S. Kellmann, M. Kiefer, A. Linden, R. Ruhnke and H. Fischer, Atmos. Chem. Phys., 2012, 12, 4923-4933.

262 M. J. Loeffler, U. Raut, R. A. Vidal, R. A. Baragiola and R. W. Carlson, Icarus, 2006, 180, 265-273.

263 S. Nandi, A. Sanov, N. Delaney, J. Faeder, R. Parson and W. C. Lineberger, J. Phys. Chem., 1998, 102, 8827.

264 J. Takagi and K. Ishigure, Nucl. Sci. Eng., 1985, 89, 177-186. 265 G. V. Buxton, C. L. Greenstock, W. P. Helman and A. B. Ross, J. Phys. Chem. Ref. Data, 1988, 17, 513-886.

266 H. Christensen, K. Sehested and T. Løgager, Radiat. Phys. Chem., 1994, 43, 527-531.

267 M. Knapp, O. Echt, D. Kreisle and E. Recknagel, J. Phys. Chem., 1987, 91, 2601-2607.

268 U. Pöschl, Angew. Chem., Int. Ed., 2005, 44, 7520-7540. 